\title{
Does Inter-municipal Cooperation promote efficiency gains? Evidence from Italian Municipal Unions
}

\author{
Massimiliano Ferraresi* Giuseppe Migali ${ }^{\dagger}$ Leonzio Rizzo ${ }^{\ddagger}$
}

\author{
March 6, 2018
}

\begin{abstract}
Inter-municipal cooperation is a common way to provide local public services, exploit economies of scale and internalize externalities. However, little is known about possible efficiency gains. We test their existence in terms of local public expenditures reductions, by investigating the Italian experience of municipal unions. We adopt quasi-experimental methodologies using administrative data on municipalities in the Emilia Romagna region. We find that being in a municipal union reduces the total per capita current expenditures by around 5 percent, without affecting the level of local public services. The effect is robust, persistent and increasing up to six years after entrance.
\end{abstract}

JEL Classification: H71, H72, C23

Keywords: municipal union cooperation, public expenditure, difference-in-differences, matching.

\footnotetext{
*massimiliano.ferraresi@ec.europa.eu, European Commission - DG Joint Research Centre Directorate I Competences - Modelling, Indicators and Impact Evaluation Unit, Via E.Fermi 2749, TP 361 Ispra (VA), I-21027, Italy

$\dagger^{\dagger}$ g.migali@lancaster.ac.uk, Department of Economics, Lancaster University Management School, Bailrigg Lancaster LA1 4YX, UK. Dipartimento S.G.S.E.S., Universita' Magna Graecia, Catanzaro, Italy.

${ }^{\ddagger}$ leonzio.rizzo@unife.it, University of Ferrara and IEB Barcelona.
} 


\section{INTRODUCTION}

In the last fifty years municipalities across Europe have faced different economic and government budget challenges that put pressure on their performances in terms of efficiency, effectiveness and quality of public services. On the one hand, the demand for the provision of public goods has registered a general increase. Citizens are more conscious and demand a wider and more skilled set of public goods, together with greater level of accountability than in the past. On the other hand, the fulfilment of the EU fiscal discipline on public finance requirements, imposed by central governments to local governments, has led municipalities to reduce their expenditures (Bell \& Warner, 2015). Therefore, municipalities especially small ones - might find difficult to meet the demands of standard levels of local public goods while reducing their expenditure. Indeed, their territorial scale is too small to efficiently provide high standard level of public services (Hulst et al., 2009). To deal with these issues, central governments are experiencing institutional tools, such as amalgamation of municipalities and inter-municipal cooperation.

Municipal amalgamation is very different from inter-municipal cooperation, and aims to reduce the number of units of sub-national governments, by compulsory merging neighbouring borders and creating new entities. The objective of municipal amalgamation is to achieve efficiency gains, from both the exploitation of economies of scale, since a larger area can be served after the coordination agreements, and the internalization of externalities (Oates, 1972; Case et al., 1993). However, the municipal amalgamation is difficult to achieve because of the strong opposition of local policy-makers, who may have to renounce to their decision-making powers (Mello \& Lago-Penas, 2013).

An alternative tool to the amalgamation process is the inter-municipal cooperation, a governance structure where municipalities reciprocally cooperate in order to provide a wide range of public services or organize service delivery between partners. Within this framework, the degree of institutionalization and the extent of decision-making powers are key elements (van Montfort \& Hulst, 2011). In fact, municipalities can transfer some public 
services to a standing organization, which would be a new entity along with the cooperating municipalities. Thus, municipalities enter into a formal agreement to co-operate with the standing organization without, however, being replaced by it.

The literature (Dollery et al., 2006; Feiock \& Scholz, 2009; Mello \& Lago-Penas, 2013; Blaeschke, 2014) has shown that the inter-municipal cooperation is a more flexible solution than amalgamation. Municipalities can maintain, on their own territory, local political representatives and decision power on fiscal policy. Moreover, inter-municipal cooperation can avoid the common pool problem ${ }^{1}$, typical of municipal amalgamation. Several empirical papers show, indeed, that free-riding incentives occur among municipalities before the process of amalgamation. In particular, Hinnerich (2009) and Jordahl and Liang (2010) exploit two different Swedish reforms, which impose local governments to merge, and demonstrate that municipalities have an incentive to accumulate debt before a merger takes place. Hansen (2014) analyzes the 2007 Danish municipal merger reform, showing that current expenditures and budget overrun before amalgamation. Yet, Saarimaa and Tukiainen (2015), using Finnish data, find that municipalities before amalgamation shift part of the costs of additional expenditures to the future partners, by increasing debt or liquidating assets. Similar findings are reported by Fritz and Feld (2015), who observe higher debt dynamics for a sample of amalgamated German municipalities. They also show that debt dynamics are higher if the number of amalgamated municipalities increases, and if municipalities are forced to merge. $^{2}$

Most empirical works have focused on the determinants of the inter-municipal cooperation. In particular, relevant factors in favour of inter-municipal cooperation appear to be the size of municipalities (Brasington, 2003; Carr et al., 2007), regional characteristics (Feiock, 2007; LeRoux \& Carr, 2007), geographic factors (Morgan \& Hirlinger, 1991; Post, 2002),

\footnotetext{
${ }^{1}$ Weingast et al. (1981) shows that inefficiency, total spending and free-riding incentives tend to increase with the number of districts (the so-called "law of $1 / n$ "), thus reflecting the fact that when local jurisdictions are to be merged common pool problems are likely to occur.

${ }^{2}$ Kauder (2016) also studies German municipal mergers, focusing on the population growth in merged municipalities. By employing propensity score matching techniques, he finds that the population of small incorporated municipalities grew faster than the population of small independent municipalities.
} 
fiscal revenue (Di Porto et al., 2013) and spatial proximity of municipalities (Di Porto et al., 2016). However, few studies have analyzed the impact of inter-municipal cooperation on socio-economic variables, focusing, instead, either on specific services (see Bel et al., 2012) and (Brasington, 1999, 2003) for the case of solid waste services and public schooling, respectively) or on a particular spending field (e.g. Allers \& de Greef, 2017) use the share of tax collection spending). Thus, to the best of our knowledge, no one has empirically explored the ex-post local impact of inter-municipal cooperation, by considering both financial and service outcomes. ${ }^{3}$

The aim of this paper is to fill this gap in the literature, by studying the effect of intermunicipal cooperation on local spending and on the provision of local public services. More specifically, we investigate the Italian experience in the inter-municipal cooperation process, ${ }^{4}$ which starts in 1990 with the institution of the municipal union (Unione dei Comuni). We use unique administrative data, that allow us to observe municipalities belonging to the region Emilia Romagna - one of the most active Italian region in promoting inter-municipal cooperation - over the period 2001-2011.

Our contribution is also related to the methodologies applied. Compared to the analyses of Brasington (1999, 2003) and Bel et al. (2012), who rely on cross-sectional variations, we are able to exploit the panel dimension of our data, more precisely the different timing in

\footnotetext{
${ }^{3}$ Instead, there is a recent strand of literature testing the effect of amalgamation on municipal financial outcomes. Reingewertz (2012), by using Israelis data, finds that amalgamated municipalities display lower per capita expenditure after amalgamation with respect to other municipalities. The same results are found for German (Blesse and Baskaran, 2016) and Swedish municipalities, although the results of the latter hold only if municipalities do not exceed a critical size (Hanes, 2015). On the contrary, Moisio and Uusitalo (2013), find that Finnish municipalities' spending was higher in the merged municipalities, even ten years after amalgamation. Roesel (2017) applies a synthetic control method to state-level aggregates of German districts, finding that mergers of large local governments do not reduce per capita total expenditures and specific per capita expenditures in categories such as social care, education or administration. Finally, Allers and Geertsema (2016), using data on Dutch municipalities, find no significant effect of amalgamation on aggregate spending, on taxation and on the level of public services. Interestingly, in a recent paper, Lima and Silveira Neto (2018) - by using data from Brazilian local governments - investigate the impact of the municipal secessions on local expenditure, showing that municipalities involved in the secession process increase the per capita capital expenditure.

${ }^{4}$ The number of municipal unions has notably increased over the time. In 2009, for example, the municipal unions were 289 , involving 1,335 municipalities (17 percent of total municipalities), while, in 2016, the municipal unions are 537, involving 3,117 municipalities (39 percent of total municipalities).
} 
entering/forming municipal unions and the permanence in a Union. Furthermore, while the existing literature has employed maximum likelihood (Brasington, 1999, 2003), probit (Bel et al., 2012) and system-GMM estimators (Allers \& de Greef, 2017) to identify the impact of municipal cooperation on public outcomes, in our work we employ counterfactual impact evaluation methods, such as difference-in-differences. Yet, to control for the different sources of biases that may arise due to the heterogeneity of the municipalities in the sample, we adopt parametric and non-parametric difference-in-differences matching models.

We find that being a member of a municipal union reduces total current per-capita expenditures by around 5 percent, compared to municipalities not in a Union. We are also able to investigate the persistence of the policy effect, and we find that the expenditure reduction is consistent and increasing up to six years after joining a municipal union. Moreover, our results indicate that the reduction of the municipal expenditure is not driven by the size of the municipality, and it is not related to the number of municipalities in the Union.

Our results are robust to several checks, which all point to a significant reduction of municipal expenditures after participating to a municipal union. Our findings are also confirmed by repeating our main analysis using data from municipalities located in Toscana, a neighbouring region similar to Emilia Romagna.

Finally, our dataset contains annual information at municipal level on some public service indicators, which we use to directly test the efficiency in the provision of local services. This is an important advantage compared to similar studies (e.g. Allers \& de Greef, 2017). We find that spending cuts are not associated with a downsizing of local services, and municipal cooperation might (marginally) reduce local tax revenues. Overall, these results confirm that the Union is effectively increasing municipalities efficiency.

The paper is organized as follows, Section 2 describes the institutional background, and Section 3 our data. Section 4 and Section 5 illustrate, respectively, empirical approach and robustness checks. Section 6 comments our findings. Section 7 shows the results for alternative outputs, and Section 8 concludes. 


\section{INSTITUTIONAL FRAMEWORK}

The Italian Constitution counts five administrative government layers: from central government to, at local level, Regions, Provinces, Metropolitan Area and Municipalities. While most Regions and Provinces are ruled by "ordinary" statutes, some of them - the "autonomous" Regions and Provinces - are ruled by "special" statutes 5 . Municipalities are the nearest jurisdiction level to the citizens, and they are in charge of several public functions in the fields of social welfare services, territorial development, local transport, infant school education, sports and cultural facilities, local police services, water delivery, waste disposal and infrastructural spending.

In Italy, there are more than 8,000 municipalities and, approximately 70 percent of them have a population lower than 5,000 inhabitants. The presence of so many small municipalities has led the national government, over the last 25 years, to stimulate processes of both amalgamation and inter-municipal cooperation. In particular, the inter-municipal cooperation has formally been introduced by the Law 142/1990, which allows municipalities to transfer their own decision-making powers, in terms of expenditure decisions, to a standing organization called municipal union (Unione di Comuni). The Italian municipal unions can be compared to the Mancomunidades in Spain, the Intergemeentelijke diensten in Netherlands, the Zweckverbande in Germany, the Sivu, Sivom, Syndicats mixtes in France and the Opdrachthoudende \& dienstverlenede verenigimgen in Belgium/Flanders.

According to the Law 142/1990, a municipal union provides the public services transferred by the cooperating municipalities. In this framework, municipalities transfer the money related to the public function(s) they want to share, and the Union provides the corresponding service(s). Therefore, the Union is a legal entity, with its own balance sheet, its own president - chosen among the mayors of municipalities joining the Union - and its own council composed by the council members of cooperating municipalities. Moreover, the Italian law

\footnotetext{
${ }^{5}$ There are five Autonomous Regions (Sicilia and Sardegna, which are insular territories, and Valle d'Aosta, Trentino Alto Adige and Friuli Venezia Giulia, which are northern boundary territories) and two Autonomous Provinces (Trento and Bolzano).
} 
prescribes that each municipality can be member of only one Union. A municipality can leave a Union, according to the rules defined in its own statute, and afterward can decide to join another Union.

In financial terms, the share of the municipal unions budget on the total expenditure of local governments has increased over time. For example, in 2007, the total expenditures of municipal unions accounted for about 0.10 percent (403 millions of euro) of the total local expenditures in Italy (350 billion of euro). In 2013, the total expenditures of municipal unions are more than doubled, accounting for about 0.30 percent (970 millions of euro) of the total local expenditures in Italy (334 billions of euro). However, these percentages do underestimate the real expenditure quota of the Unions, because municipalities do not often write off their quota of the delegated function, and continue to register it as their own expenditure.

As revenues are concerned, the municipal union relies on both transfers from municipalities within the Union and transfers from higher level of governments (State and regional governments). These transfers are generally intended as a way to support Unions for all costs related to the organization of local services in a cooperative way. It is also worth noticing that municipal unions are exempted from the internal stability pact, a set of fiscal rules imposed by the central government to each municipality above 5,000 inhabitants.

The functions commonly transferred to the Unions are Administration and Management, Municipal police, Education, Roads and Transport Services, Planning and Environment and Social welfare. Municipalities can also transfer other functions, such as Economic development, In-house production services, Culture, Sport and Tourism.

More precisely, the main tasks within the Administration and Management function are related to the management of the personnel, recruitment, training and definition of the legal and economic status of the staff. With regards to the Municipal police function, the services assigned to the Union concern the application of the municipal regulations, road safety, protection of business and consumer freedom, protection of living and urban safety, rural safety, 
security and regular work, control of local tributes and civil protection. The Education services usually associated with a municipal union are: nursery and childcare, auxiliary services to education, teaching and training (such as, canteen, school transport, support for disabled people), and development of educational projects. The Roads and Transport Services, and the Planning and Environment tasks delegated to the Union include: development of urban planning tools, maintenance of the road and traffic system, management of cadastral functions, urban planning and anti-seismic vigilance and control. In addition, the Union also carries out the preparation and the management of the Triennial Public Works Program (Piano Triennale delle Opere Pubbliche). For the Social welfare, tasks devoted to the Union concern measures against poverty and social inclusion, support for elderly and young people, social services in support of disabled people, accreditation of socio-sanitary structures. Economic development and In-House production duties delegated to the Union are: information services, administration and management of local networks, database management and acquisition, hardware and software purchase, staff training and statistical services. Although it is not very common, municipal union can also be delegated to deal with culture, sport and tourism. Unions may be in charge of the organisation of public events, management of libraries, museums and sport facilities, such as swimming pools and stadia. Municipal unions may also organize local reception of tourists and information points.

Benefits from cooperation in the provision of all these services are mainly due to the exploitation of economies of scale and the reduction in the number of tasks (unnecessarily) undertaken by each municipality. In this way, duplication of public functions are avoided, costs can be shared and, eventually, new public services provided. For example, the cooperation on the Municipal police function has allowed the introduction of the neighbourhood policeman (poliziotto di quartiere) and the reinforcement of the night and festive police services. ${ }^{6}$ Consequently, cooperation induces municipalities to review their procedures and

\footnotetext{
${ }^{6}$ For illustrative purpose, we collect information (from the balance sheet of each single municipality) on the number of municipal policemen and its relative expenditure. Then, for each municipality belonging to the municipal union, we compare the number of policemen, before and after the municipality entered the Union. The results indicate that before entering the Union, municipalities have, on average, 7 policemen,
} 
operations which, in turn, may result in an increase of efficiency (Hansen et al., 2014).

Regional administrations are endowed with strong regulatory powers regarding municipalities belonging to Unions. In particular, regions have a prominent role in monitoring and evaluating all the processes of municipal cooperation, in order to promptly intervene if any issue arises. ${ }^{7}$ Regions also provide municipalities and Unions with both legal advices and feasibility studies during the Union's formation process. In addition, each region, through its own law, can stimulate and promote Municipal Unions within its territory, mainly by means of regional transfers. Some regions - such as Veneto, Toscana and Emilia Romagna - sustained the creation of municipal unions using different financial incentives (e.g length of permanence or size of the Union), whereas other regions did not promote any form of support. A particular case is Lombardia, which has created a special register of municipal unions (Unioni di Comuni Lombardi), such that only registered municipalities have access to regional transfers.

\section{DATA}

As discussed in the previous section, the regional administrations regulate and implement the municipal unions through their own laws. Consequently, the organisation process has not been homogeneous both over space, i.e. across regions in Italy, and over time (during the period of our analysis 2001-2011). This implies that municipalities in Unions located in different regions are not properly comparable, and we cannot identify a unique (aggregate) effect of the policy on local expenditures.

We have therefore decided to restrict our main analysis to one region only, Emilia Romagna and to consider a second region, Toscana, to assess the robustness and the general

and the level of expenditure for the municipal police service is equal to 31 euros per-capita. After entering a Union, the number of policemen is halved (on average 3.50) and the level of expenditure for the municipal police service reduces to 25 euros per-capita. Note that the difference in the number of policemen, before and after the entrance in the union $(3.50=7-3.50)$ is statistically significant at 1 percent as well as the difference in per-capita expenditure $(6=31-25)$.

${ }^{7}$ Most often, these issues concern the "cultural" resistance of municipalities to cooperate. 
validity of our results. Our choice depends, first of all, on the availability of rich data on all municipalities in Emilia Romagna. We use information resulting from a combination of different archives publicly available from the Italian Ministry of the Interior, the Italian Ministry of Economy and the Italian Institute of Statistic (ISTAT). Our data include a full range of information: 1) municipal financial data, such as total current expenditures, public debt, revenues; 2) municipal demographic and socio-economic data, such as, population size, age, average income of inhabitants, birth rate, net migration, number of children enrolled at primary school ; 3) other output data, such as waste collection, road accidents and kindergarten supply. The details on data sources are reported in Table A.1

Second, Emilia Romagna is one of the biggest and wealthiest Italian regions. It is located in the North and its average population in the period of our analysis, 2001-2011, has been around 4 million inhabitants (approximately 7.50 percent of the Italian population). The average GDP, over the same period, has been 116 billion euros (approximately 9 percent of the Italian GDP).

Third, inter-municipal cooperation is a widespread phenomenon throughout Emilia Romagna. During the last decade, indeed, the number of Municipal Union has noticeably increased, involving the greatest proportion of municipalities among ordinary status regions.

Thus we think that the effect of municipal unions in this region may be a good predictor of the overall efficacy of the policy.

\subsection{Municipal unions in Emilia Romagna}

In our data we can observe 348 municipalities in Emilia Romagna, for the period 2001-2011. However, we exclude Bologna because of its specific status of Metropolitan Area, which normally provides a much wider range of services than other municipalities. Moreover, due to missing values in some variable of interest our final sample reduces to 335 municipalities, or a total of 3,686 observation in the period under investigation. ${ }^{8}$

\footnotetext{
${ }^{8}$ Summary and descriptive statistics are reported in Table A.2 .
} 
We know the exact year of entrance of a municipality in a Union, and Figures 1 and 2 show a map of all municipalities in Emilia Romagna in 2001 and 2011, highlighting those in a Union, while in Table 1 we report the number of municipalities in Union and not in Union, for each year from 2001 to 2011. We notice that in 2001 (Figure 1) there is only one municipal union, including 9 municipalities (2.67 percent of the total) and serving 20,767 inhabitants, around 1 percent of the regional population. Figure 2 shows a completely different picture in 2011: there are 31 municipal unions involving 160 municipalities (47.06 percent of the total) and serving 1.5 million of inhabitants, that is 34 percent of the total population of Emilia Romagna. Focusing on Table 1, the bulk of municipalities forming and/or joining a Union occurred between 2007 and 2009. Indeed, in 2007, 54 municipalities (16.12 percent) were in a Union, while in 2008 the number of municipalities in a Union increased up to 70 (20.83 percent). Finally, for the years 2009 and 2010, the municipalities in Union were 132 (39.88 percent) and 150 (43.73 percent), respectively. ${ }^{9}$

\section{PLACE FIGURE 1, FIGURE 2 AND TABLE 1 HERE}

Municipal unions are composed, on average, by 5 municipalities (from a minimum of 2 to a maximum of 10) and cover an average population of approximately 43,000 inhabitants. The Unione Valle Tidone, includes only two municipalities, and it is the smallest serving 3,096 people. The Unione Comuni Modenesi del Distretto Ceramico, is composed by 4 municipalities, and it is the largest Union serving 107,138 inhabitants.

The decision to enter a Union belongs to the single municipality, even though the regional government has the power to regulate the process of inter-municipal cooperation. Specifically, the government of the Emilia Romagna approved in 2008 an important regional law (LR 2008, n.10) aiming at rationalising public expenditures through a reorganisation of the institutional bodies on its territory. Emilia Romagna transformed the mountain communities

\footnotetext{
${ }^{9}$ The trend is continuously growing and by 2016 the percentage of municipalities in unions is 81 percent.
} 
(an institutional organisation formed only by mountain municipalities) in municipal unions and strongly encouraged municipalities to form Unions, giving to the latter direct financial incentives.

As a consequence of the regional law, the total amount of regional transfers to municipal unions immediately increased from 2 million euros in 2007 to 4.6 million euros in 2008. This corresponds to an average increase for each municipal union from 198,759 euros to 289,779 euros. $^{10}$ Transfers are attributed according to: i) the type and the number of spending functions / services assigned to the Union; ii) demographic density, number of municipalities and overall population of the Union and iii) staff transferred to the Union.

\subsection{Expenditures}

We consider the total current expenditure of each municipality, in per-capita terms, as an aggregate measure to compare the performances of municipalities in Union and not in Union.

It is important to note that the total current expenditure for municipalities in a Union includes their transfers to the Union. Indeed, the services provided by the Unions are essentially financed through those transfers and by direct expenditures registered in the budget of the municipalities. However, we do not have information on the amount transferred to the Union, disaggregated by single items of the municipality budget. This implies that any analysis that find an effect on sub-categories of expenditure would be biased. ${ }^{11}$

As a preliminary piece of evidence, it is interesting to see that the average per capita expenditure of municipalities in Union is 751.10 euros whereas for the others is 835.99 euros. This gives a differences of 84.88 euros p.c. ${ }^{12}$ which is statistically significant at 1 percent.

\footnotetext{
${ }^{10}$ The regional transfers to municipal unions have continued to increase averaging to $314,543,307,792$ and 326,204 euros, for the years 2009, 2010 and 2011, respectively.

${ }^{11}$ Consider, for example, a municipality not in a Union that in year $\mathrm{T}$ spends for the police function 100 euros. Now assume that the same municipality joins a Union in year $\mathrm{T}+1$ and transfers a certain amount of money for the municipal police (say 100) and other functions now provided by the Union. Then, in the budget of the municipality we would observe zero expenditures for the municipal police, however the true value for this specific item of the budget would still be 100, since it would correspond to the amount transferred from the municipality to the Union for the provision of the municipal police service.

${ }^{12}$ From now on per capita is reported as p.c.
} 
Figure 3 depicts the evolution of the (logs of) current expenditure p.c. for municipalities in Union and not in Union. The trends look a bit different in the first 3 years of the sample, however there are at most 5 Unions and 23 municipalities (see Table 1). From 2004 to 2007 the trends are similar, and afterwards they start to diverge, with an important decrease in the expenditure of municipalities in Union after 2009. Notice that this timing corresponds to the introduction in 2008 of the regional reform law mentioned above, which has increased the regional transfers to Unions and it has been followed by a strong increase in their number.

\section{PLACE FIGURE 3 HERE}

\section{EMPIRICAL APPROACH}

In this section we describe the main strategies to identify the effect of being a member of a municipal union on the spending decisions of single municipalities. Ideally, we would like to compare decisions on expenditure for municipalities in a Union (treated group), to the same decisions for municipalities in the counterfactual situation of not being in a Union. This is impossible, and the best alternative would be a randomized control trial which assigns participation and non participation in a municipal union across municipalities, and allows us to compare the average expenditures of the two groups. In our analysis, however, we have to rely on quasi-experimental methods to define a suitable control group that can credibly estimate the counterfactual. The main concern on the identification using these approaches is due to the unobservable characteristics that may vary between municipalities in Union and not, and which might be correlated to the expenditures: a concern we try to address in what follows. 


\subsection{Difference-in-differences}

The first approach that we implement is a difference-in-differences (DiD) methodology, since we can exploit the panel dimension of our data and attempt to remove the unobservables that are fixed over time. For each year, we have municipalities in Unions (treated group) and municipalities not in Unions (control group). We therefore compare the change in expenditures in the treatment group before and after the participation in a municipal union, to the change in expenditures in the control group for the same period.

We estimate the following two-way fixed effect linear model

$$
Y_{i t}=\mu_{i}+\tau_{t}+\gamma M U_{i t}+\beta \mathbf{x}_{\mathbf{i t}}+\varepsilon_{\mathbf{i t}}
$$

where $Y_{i t}$ is $\log$ per capita expenditure in municipality $i$ at time $t, M U_{i t}$ is a dummy variable that takes the value one if municipality $i$ at time $t$ belongs to the Municipal Union and zero otherwise. $\mu_{i}$ are a set of municipalities fixed effects, and we also control for exogenous shocks, $\tau_{t}$, common to all municipalities in period $t . \mathbf{x}_{\mathbf{i t}}$ is a vector of time-varying variables, accounting for demographic and socio-economic characteristics. In particular, following the literature on the determinants of local spending (Revelli, 2003; Solè-Ollè, 2006; Veiga \& Veiga, 2007; Ferraresi et al., 2018), we include the population of the municipality (population), the per capita area, calculated as square kilometers divided by population (area squared $\mathrm{km})$, and the inverse of the population (1/population). These variables can capture the presence of scale economies or dis-economies in the provision of public goods and congestion effects. The proportion of citizens aged between 0 and 5 (population $\leq 5$ ) and the proportion of citizens aged over 65 (population $\geq 65$ ) can account for some specific public needs (e.g., nursery school, nursing homes for the elderly). In terms of economic and financial controls, we include the average per capita income proxied by the personal income tax base (income) and the proportion of taxpayers (taxpayers). Moreover, we define a dummy variable (election), which, during the period 2001-2011, is equal to 1 for a given municipality 
in the year of election. ${ }^{13}$

Finally, the error term $\varepsilon_{i t}$ is assumed to be independent of $\mu_{i}$ and $\tau_{t}$, and we cluster the standard errors at municipal level. In this framework, $\gamma$, is the difference-in-difference estimate of the effect of being in a municipal union on expenditure.

\section{DiD assumptions}

The main assumption for the validity of the difference-in-differences method is the presence of pre-treatment common trends for municipalities in both the treatment and control groups. Figure 3 is not helpful for a visual inspection of the pre-treatment trends since we are using treatments at different times. Therefore, we perform a formal test by re-estimating equation 1, including the interactions of the time dummies and the treatment indicator for the first three pre-treatment periods. If the expenditure trends between treatment and control group are the same, then the coefficients of the interactions should be not statistically significant, i.e. the difference in differences is not significantly different between the two groups in the pre-treatment period. An attractive feature of this test is that also the interaction of the time dummies after the treatment (up to 2 years) with the treatment indicator is informative, it can show whether the treatment effect changes over time. The literature generally refers to the interactions of the treatment indicator with the pre-treatment periods as "leads" and the interaction with the post-treatment time dummies as "lags". ${ }^{14}$ In our analysis, we estimate the following version of equation 1:

$$
Y_{i t}=\mu_{i}+\tau_{t}+\sum_{j=0}^{2} \gamma_{-j} M U_{i, t-j}+\sum_{j=1}^{3} \gamma_{+j} M U_{i, t+j}+\beta \mathbf{x}_{\mathbf{i t}}+\varepsilon_{\mathbf{i t}}
$$

where the sum of $\gamma_{-j}$ allows for 2 lags effects and the sum of $\gamma_{+j}$ allows for 3 leads or anticipatory effects. A test of the difference in differences assumption is $\gamma_{+j}=0$ for each

\footnotetext{
${ }^{13}$ Since Italian municipalities have staggered times of elections it is feasible to include, simultaneously, a dummy variable for municipal election and annual fixed effects. In this way we can distinguish the effect of being in an electoral year from other fluctuations due, for example, to changes in macroeconomic conditions.

${ }^{14}$ See Autor (2003) for an application of this method.
} 
$j=1,2,3$, i.e. the coefficients of all leads of the treatment should be zero. Furthermore, $\gamma_{-j}$ may not be identical and if the effect of the treatment is growing over time $\gamma_{-j}$ increases in $j$.

\subsection{Propensity score matching models}

The approach discussed so far might, however, suffer of two potential sources of bias, because the effect of entering a Union is not homogeneous and varies according to the characteristics of the municipalities. The first bias, indeed, arises when municipalities in the treatment group are somehow different than those belonging to the the control group. The second source of bias might be due to different distributions, within the treatment and the control groups, in the vector of observable characteristics that affect expenditures.

We attempt to eliminate these biases in the estimations by adopting propensity score matching models. The main purpose of matching is to find a group of non-treated municipalities, who are similar to the treated in all relevant pre-treatment characteristics, $\mathbf{x}$, the only remaining difference being that one group enters a Union and another group does not.

In the first stage we therefore estimate the propensity score ${ }^{15}$ using a discrete response model of entering a municipal union. In particular, we use data from the 2001 Census and run a probit regression, where the dependent variable is given by a dummy variable which takes the value of 1 if a municipality entered in the municipal union during the period 20012011 and zero otherwise. The included control variables are: a dummy variable equal to 1 if the municipality is located in a seismic zone (seismic area), a dummy variable equal to 1 if the municipality is a rural municipality and zero otherwise (rural area); per capita surface in square $\mathrm{km}$ of the municipality (area p.c.); a categorical variable (altitude profile) equal to 1 if the municipality is located in plain, equal to 2 if the municipality is located on hills, and equal to 3 if the municipality is located in mountains; municipal unemployment rate (unemployment); number of houses (dwellings); number of firms (firms). We also include

\footnotetext{
${ }^{15}$ The probability of entering a Union conditional on pre-treatment characteristics $\mathbf{x}, P(\mathbf{x})=\operatorname{Pr}(M U=$ $1 \mid \mathbf{x})$
} 
population, population disaggregated by age and inverse population; income, taxpayers, and a continuous variable that measures the level of municipal debt expressed in per-capita term (debts). All these variables refer to the year 2001. The results of the estimation of the propensity score model are reported in Table A.3 in the Appendix A. Once we have obtained the propensity score (PS), following Smith and Todd (2005), we adopt a trimming procedure to define the common support as the region of values of PS that have positive density within both the treatment and control groups distributions. ${ }^{16}$ We then re-estimate equation 1 by using information only on the observations that lie on the common support.

However, within the common support, the distribution of $\mathbf{x}$ might be different between treated and control observations, keeping the second source of bias. Therefore, we control for it by using a non-parametric DiD kernel matching estimator. ${ }^{17}$ Following Heckman et al. (1998), we estimate

$$
\gamma^{D i D}=\sum_{i \in M U}\left\{\left[Y_{i t_{1}}-Y_{i t_{0}}\right]-\sum_{j \in N M U} W_{i j}\left[Y_{j t_{1}}-Y_{j t_{0}}\right]\right\} w_{i}
$$

where $t_{0}$ and $t_{1}$ are time periods before and after entering a Union. Specifically, $M U$ is formed by municipalities not in municipal union in $t_{0}$ that will join a Union in $t_{1}, N M U$ is formed by municipalities not in municipal union in $t_{0}$ that will remain out of any Union in $t_{1} . W_{i j}$ is the weight placed on the $j$ th observation in constructing the counterfactual for the $i$ th treated observation. $Y$ is the expenditure of municipalities and $w_{i}$ is the reweighting that reconstructs the outcome distribution for the treated sample. In order to have a balanced sample between the two comparison groups, we choose the years 2008 and 2010 as pre-treatment and pos-treatment period, respectively.

We have already mentioned the important regional reform law approved in Emilia Ro-

\footnotetext{
${ }^{16}$ In particular, following (Galiani et al., 2005), we also trim the propensity scores distribution eliminating those municipalities with values lower than the first percentile and higher than the ninety-ninth percentile. Overall, from the matching procedure we exclude approximately 10 percent of municipalities from our sample.

${ }^{17}$ The Kernel matching approach has been performed by using the Stata command diff developed by Villa (2012). The standard errors are clustered at municipal level.
} 
magna in 2008, and the subsequent strong increase in the number of municipalities that entered and/or formed a Union (this pattern is clear looking at Table 1). Hence, in the treatment group we include only municipalities that join a municipal union in 2009, and in the control group municipalities that never joined a Union. We then perform the matching approach as in equation 3, by comparing expenditure between treated and control municipalities, in 2008 and in 2010.

\subsection{Heterogeneity}

To investigate whether there is evidence of heterogeneity, we observe how the effect of the policy varies with respect to the permanence in a municipal union. In fact, the model in equation 1 does not directly take into account of the length of time spent by each municipality in the Union after joining it. This is an important issue since we are dealing with multiple treatment groups and multiple time periods. We, therefore, estimate a modified version of equation 1, where we add a continuous variable that measures the permanence (permanence) in the Union (from zero to 11 years), and we also include its quadratic term (permanence square). We then evaluate the effect of the permanence in each year, separately.

Another source of heterogeneity that may affect expenditure savings is the size of the municipalities entering the Union. Indeed, we expect a bigger effect for small municipalities joining a Union, since they can exploit higher economies of scale, compared to large municipalities. Therefore, we build a new variable, $\operatorname{large}_{i t}$, which takes on the value of one if the municipal population is above the average population of all municipalities in the Union (around 8,000 inhabitants) and zero otherwise. This variable is then interacted with $M U_{i t}$ and we estimate the following version of equation 1 :

$$
Y_{i t}=\mu_{i}+\tau_{t}+\gamma M U_{i t}+\lambda M U_{i t} \times \operatorname{Large}_{i t}+\beta x_{i t}+\epsilon_{i t}
$$

In this case, $\gamma$ captures the effect of being in a municipal union for small municipalities, while 
$\lambda$ accounts for the the differential effect of being in a municipal union for large municipalities.

Finally, being in a Union formed by a large number of municipalities may be more demanding in terms of organization costs and coordination than being in a Union with a relatively small number of municipalities. We control for the number of municipalities in Union, by defining a new variable, Unionsize Un $_{i}$, which varies from a minimum of 2 to a maximum of 10 municipalities within a given municipal union. We interact this variable with $M U_{i t}$ and we re-estimate the following version of equation 4 :

$$
Y_{i t}=\mu_{i}+\tau_{t}+\gamma M U_{i t}+\lambda M U_{i t} \times \text { Unionsize }_{i t}+\beta x_{i t}+\epsilon_{i t}
$$

where $\gamma+\lambda \times$ Unionsize $_{i t}$ is the effect of being in a municipal union on expenditure, which now depends on the number of municipalities.

We replicate all the analysis discussed to detect heterogeneity both in the full and in the matched samples of municipalities.

\section{ROBUSTNESS CHECKS}

We provide a series of tests and alternative specifications to assess whether our results are robust, and confirm a reduction in municipality expenditures after joining a Union.

\section{$5.1 \quad$ Reverse causality}

The validity of our results relies on the assumption of absence of reverse causality, that is we exclude any direct effect of expenditure on the decision to join a municipal union. In order to test this assumption we estimate the conditional probability, $h_{i t}$, to enter a Union for a municipality $i$ at time $t$, given that the event has not yet occurred. Following Jenkins (1995) we specify the form of the hazard function as a complementary log-log hazard rate and we use a piecewise-constant baseline hazard by including dummy variables for each year. Thus, within each time interval the duration dependence is assumed constant. This represents a 
semi-parametric, discrete-time, homogenous hazard model which can be written as

$$
h_{i t}=1-\exp \left(-\exp \left(\alpha \mathbf{d}_{\mathbf{i t}}+\beta \mathbf{x}_{\mathbf{i t}}+\eta Y_{i t}\right)\right)
$$

where the vector $\mathbf{x}_{\mathbf{i t}}$ includes all the control variables described in section 4 and annual fixed effects. $Y_{i t}$ is the $(\log )$ expenditure. We also estimate a heterogenous hazard model, generalising equation 6 to account for any unobserved municipality-specific effect by including a random intercept $q_{i}$, which is uncorrelated with all the covariates (Narendranathan \& Stewart, 1993). Our hypothesis is that the coefficient $\eta$ of log expenditures is not significant, i.e. there is no reverse causality.

\subsection{Transfers}

A potential source of bias that might affect our results is the omission of transfers and/or revenue collected by the Union. Indeed, we cannot properly separate the effect of being in a municipal union from the variation in the financial resources raised by the municipal union. ${ }^{18}$ To deal with this issue, we define a set of variables capturing the amount of transfers and revenues collected by the municipal union. In particular, we re-estimate equation 1 , both in the full and matched samples, by including 3 variables that account for the transfers to the municipal union from: central government (state grants), regional government (regional grants) and other bodies (other bodies grants). We also add a fourth variable that measures the resources raised by the Union (other revenues). Since these variables change each year only at municipal union level, all the municipalities belonging to the same Union have the

\footnotetext{
${ }^{18}$ For example, consider a municipality $\mathrm{M}$ that enters in year $\mathrm{T}$ in a municipal union. $\mathrm{M}$ transfers a given amount of money, say 100 euros, to the Union. The total expenditure of M, including the transfer to the Union, for the year $\mathrm{T}$ is $900+100=1,000$ euros. Then, suppose that the same municipality in year $\mathrm{T}+1$ transfers to the Union a lower amount of money, say 50 euro. This because in year $\mathrm{T}+1$ the municipal union has received additional transfers from the regional government. Assume that the expenditure of municipality $\mathrm{M}$, net of the transfers to the Union, is constant (900) between year $\mathrm{T}$ and $\mathrm{T}+1$. Therefore, the total expenditure of municipality $\mathrm{M}$ in year $\mathrm{T}+1$ is 950 euro. If we compared the total expenditure of municipality $\mathrm{M}$, between year $\mathrm{T}$ and year $\mathrm{T}+1$, we would observe a reduction (from 1000 to 950). However, such a reduction, would not be due to efficiency gains resulting from the participation to the Union. On the contrary, this would be due to the reduction in transfers from the municipality to the municipal union.
} 
same value.

Moreover, in order to generate some variation at municipality level within a Union, we compute the share of all transfers and revenues for each municipality according to their population size. We then replicate the analysis including in equation 1 this new variable called Union revenues by municipalities.

\subsection{Homogenous Control Group}

We estimate our DiD model using a more homogeneous definition of the control group. Firstly, we restrict the sample to the years 2001-2008 and we exclude municipalities that never enter a Union (never treated). Then, we include in the control group the municipalities that join a Union between 2009 and 2011 (future treated) together with all the municipalities

observed in the years before entrance (within the period 2001-2008). Secondly, we estimate equation 1 in the full sample and in the matched sample of municipalities. This analysis is important because it means that we include in the control group municipalities that are simply further down the 'queue' for participation in the policy.

\subsection{Alternative Region: Toscana}

All the analyses performed so far have been based on a sample of municipalities located in Emilia Romagna. However, a potential concern might be that the selection into the treatment within Emilia Romagna is not completely random. Hence, we replicate our analysis in an alternative and more comparable region. We consider Toscana, another important administrative region located in the north of Italy and sharing a common border with Emilia Romagna. In Toscana, over the period 2001-2011, the average population has been about 3.8 million inhabitants (approximately 6 percent of the Italian population), the average GDP around 105 billion euros (approximately 8 percent of the Italian GDP). Likewise for Emilia Romagna, we have collected for Toscana financial, demographic and socio-economic data 
at municipal level. Overall, we count 263 municipalities out of $276,{ }^{19}$ leading to 2,893 observations in the period 2001-2011. Differently from Emilia Romagna, the evolution of the municipal cooperation is much less marked and starts later. According to the sources of the Ministry of Interior, in 2009 in Toscana there were only 6 municipal unions, involving 38 municipalities. In 2010 and 2011, the number of municipal unions increased to 8, involving 48 municipalities. Therefore, using the available information we evaluate the effect of joining a municipal union on expenditures, estimating equation 1 on the full sample and in the matched sample of municipalities in Toscana.

\section{RESULTS}

In Table 2 we show the difference-in-differences (DiD) estimates. In particular, in column 1 we estimate equation 1 in the full sample, including only municipality and year fixed effects. We find that being a member of a municipal union decreases the municipalities expenditures by 6.5 percent, and the effect is significant at 1 percent. One issue is that there may be municipality characteristics varying across time and space, potentially correlated to participation to a Union and expenditures. We therefore estimate our DiD model controlling for a series of demographic and socio-economic factors described in Section 4.1. The inclusion of the control variables slightly changes the magnitude of the treatment effect. In fact, looking at column 2, we notice that the coefficient of municipal union is still negative $(-4.4$ percent) and significant (at 1 percent), however it drops by 2.1 percentage points. This implies that it is important to control for differences among municipalities. The estimates in columns 4 and 5 of Table 2 are obtained restricting to the subsample of matched municipalities, and all confirm our previous fundings. This approach should control for the bias arising when municipalities in the treatment group differ from those included in the control group. In column 7 of Table 2 we report the results of the non-parametric DiD kernel matching estimation. This methodology should take into account of possible differences, between

\footnotetext{
${ }^{19}$ Unfortunately, for 13 municipalities data are not complete or missing.
} 
treatment and control groups, in the distribution of observable characteristics that influence expenditures. We again find similar results to the previous estimates: being in a municipal union reduces the expenditure by around 5.5 percent and the effect is significant at 5 percent.

\section{PLACE TABLE 2 HERE}

To assess the common trend assumption, as explained in Section 4.1, we estimate equation 2 and check whether the coefficients of the leads are statistically significant. In Figure 4 we plot the point estimates and its 95 percent confidence interval, and we do not observe any significant effect of the leads up to a pre-treatment period of 3 years. ${ }^{20}$ The coefficients of the lags, shown up to 2 years after entrance, are statistically significant and suggest that the negative effect of the municipal union on expenditure is growing over time. In Table A.5 we report the results of the estimation using the full sample and the matched sample. Overall, this test reassures on the validity of the common trend assumption.

\section{PLACE FIGURE 4 HERE}

\subsection{Heterogeneity}

As mentioned in Section 4.3, we first investigate whether the effect of joining a municipal union is affected by the length of the permanence. In column 3 of Table 2 we show that including in equation 1 a measure of permanence has a concave effect, and remaining one additional year in a Union reduces on average the expenditures by 2.8 percent. A similar effect is obtained when we repeat the analysis in the matched sample (see column 6).

\footnotetext{
${ }^{20}$ In order to build the leads variables we have collected information about the participation of the single municipality in the Municipal Union for the years 2012, 2013 and 2014. For example, the lead variable for municipality $i$ in year 2011 implies to know whether municipality $i$ will join a municipal union in 2012: if it joins a Union in 2012, the value of the lead variable for the year 2011 is equal to 1, instead, if it does not, the value of the lead variable for the year 2011 is equal to 0 .
} 
However, to better understand the dynamic of the permanence in a Union, we have disentangled the aggregate effect in annual effects, and reported the results in Table 3 . In practice, for any year of the permanence in the Union we compute the following combination: $M U+$ permanence $\times$ year + permanence square $\times$ year ${ }^{2}$, where year corresponds to the number of years for which we want to compute the effect. In columns 1, we consider the full sample, and it is interesting to observe an important reduction in expenditures after 4 years in a Union (from -4 percent to -6.9 percent). The effect is highly significant and increasing up to 6 years from the entrance in a municipal union. It slowly decreases after 7 years and then disappears. Similar results are observed in the matched sample (column 2), although with a slightly smaller magnitude.

\section{PLACE TABLE 3 HERE}

Besides the permanence, we test whether the size of the single municipalities affects the effect of being in a municipal union. In columns 1 and 3 of Table 4, we report the estimates of equation 4 in the full and the matched samples, respectively. In column 1, we notice a negative effect (-3.4 percent), statistically significant at 5 percent, for small municipalities. The coefficient associated to the term $M U_{i t} \times$ Large $_{i t}$ is still negative but not statically significant, thus indicating that the reduction in expenditure is not driven by the size of the municipality. The results do not change in the matched sample.

In columns 2 and 4 of Table 4 , we show the estimates of equation 5 , separately for the full and the matched samples. Focusing on column 2, we find that municipalities joining a Union experience a significant decrease in municipal expenditure as long as the number in the Union is lower (equal) to 9. However, the coefficient associated to the interaction term, $M U_{i t} \times$ Unionsize $_{i t}$, turns out to be not significant, thus suggesting that the reduction of the municipal expenditure does not depend on the number of municipalities in the Union. The results are qualitatively similar in the sample of matched municipalities, although less 
precisely estimated (Table 4, col. 4).

PLACE TABLE 4 HERE

\subsection{Robustness Checks}

Reverse causality. In Table 5, we report the estimates for the homogeneous and heterogeneous duration models. ${ }^{21}$ It is evident that there is no reverse causality, because the effect of expenditure on the conditional probability to enter and/or form a Union is not significant. We also notice that unobserved heterogeneity does not appear to be an issue. Indeed, the coefficient of log expenditure is identical for both models, and the hypothesis of zero unobserved heterogeneity fails to be rejected.

\section{PLACE TABLE 5 HERE}

Transfers. In Table 6, we report the results of the analysis, discussed in Section 5.2, which controls for transfers and/or revenues collected by the municipal union. Columns 1 and 4 show, for comparison purposes, our benchmark estimates of equation 1 in the full sample and in the matched sample, respectively. ${ }^{22}$ When we include, in equation 1 , central, regional and other transfers to the Union together with other revenues, the coefficient of municipal union is highly statistically significant and slightly lower than the benchmark estimate (see columns 1 and 2). In the matched sample we find identical effects (see columns 4 and 5). When we attribute the total amount of all transfers and revenues of the Unions to each municipality, according to their population size, the effect of participating in a municipal union

\footnotetext{
${ }^{21}$ For ease of interpretation we have expressed the estimated coefficient of the log expenditure variable as a hazard ratio. Results are shown more extensively in Table A.4.

${ }^{22}$ Note that these coefficients are slightly different from those in columns 2 and 5 of Table 2 , because to keep the same sample size across all the analyses we are removing 9 municipal unions - 80 observations which budget data are not available for the the period 2002-2004.
} 
is still negative, highly significant, and generally in line with the estimates in the other spec-

ifications (see columns 3 and 6, in the full and matched sample respectively). These findings are consistent with our main results, and thus indicate that transfers and own revenues of the municipal union are unlikely to be a serious source of bias.

\section{PLACE TABLE 6 HERE}

Homogenous control group. As explained in Section 5.3, we refine our definition of control group including more homogeneous municipalities and we re-estimate equation 1. Column 1 in Table 7 shows that in the full sample the effect of being in a municipal union reduces expenditures by around 7 percent. In column 2, we report the same estimation in the matched sample and the effect is still significant at 1 percent but somewhat lower. We also notice that the coefficient of municipal union is a bit larger compared to our benchmark results in Table 2 . However, taking into account the smaller sample size and the shorter time period considered, the results of this analysis are, overall, confirming our previous findings.

\section{PLACE TABLE 7 HERE}

Alternative Region: Toscana. Our last robustness check deals with the possibility of self-selection of the municipalities joining the Unions in Emilia Romagna. In Section 5.4 we have illustrated our new approach based on the choice of municipalities and Unions, located in an alternative region, Toscana, very similar and comparable to Emilia Romagna. We estimate equation 1 , both in the full and matched samples, using the same type of municipality controls employed in the analyses for Emilia Romagna. The results are reported in Table 8. In column 1, for the full sample, we observe that being in a municipal union in Toscana reduces expenditures by 3.5 percent, the effect is statically significant at 5 percent. When we repeat the estimation in the sample of matched municipalities, the effect is still negative 
although a bit smaller in magnitude (-2.6 percent) and significant at 10 percent. This test confirms that participating in a municipal union has a clear expenditure saving effect, and this effect is not limited to the Emilia Romagna region.

\section{PLACE TABLE 8 HERE}

\section{ALTERNATIVE OUTPUT}

In this section we investigate whether the inter-municipal cooperation is associated to a real increase in the efficiency of the single municipalities. In fact, the expenditure savings observed for municipalities in Union might be the consequence of a lower quality in the provision of public services.

Furthermore, we also evaluate whether inter-municipal cooperation reduces local revenues. This can occur because the expenditure savings generated by cooperation might be used by local policy makers to reduce taxes, since it is politically attractive (Allers and Geertsema, 2016).

\subsection{Provision of Public Services}

To verify whether the reduction of expenditure after joining a municipal union leads to a decrease in the provision of local public services, we would need exact measures of the quantity or quality of those services for the period 2001-2011. Unfortunately, such information is not available. Hence, following the recent literature (Allers \& Geertsema, 2016; Blesse \& Baskaran, 2016; Lima \& Neto, 2018; Reingewertz, 2012), we consider three possible measures of municipal attractiveness: per capita birth rate, net migration into municipality and per capita primary school class size. If local services were to decline we would expect a negative impact of participating to Union on these measures, as a consequence of the reduction 
in expenditures. For example, poor local public services may imply lower migration, lower birth rates could be a result of a reduced attractiveness of the municipality. Furthermore, lower expenditures may increase the school class size, a typical indicator of the quality of the school service.

Moreover, to evaluate whether the efficiency in the provision of local public services has improved after joining a municipal union, we, first, collect data on the per-capita number of road accidents. If a decrease in expenditure worsens roads or bridges maintenance, then the number of car accidents might increase. Then, we build two indicators at the municipal level. The first is given by the ratio between the number of houses served by the municipal service of domicile waste collection and the total number of houses. ${ }^{23}$ This should be a signal of the efficiency in waste collection. The second indicator is the ratio between the number of successful applications at local kindergartens and the total number of applications. This should capture the level of efficiency in the supply of kindergarten services.

The results of our estimations are reported in Table 9, for both the full sample and the matched municipality sample. In Panel A we report the estimates obtained using the measures of attractiveness. The effect of joining a municipal union is always not statistically significant, confirming that there is no decrease in municipality attractiveness. In Panel B we show the results for the indicators of efficiency. We notice that, overall, participating to a Union does not affect the provision of public services. Indeed, all coefficients are not significant except for kindergarten supply. In the latter case, we observe an increase in the rate of successful applications of approximately 4 percent, both in the full sample and the matched sample of municipalities.

Taken together, these results suggest that the inter-municipal cooperation is not associated to any reduction in the provision of public services, therefore all the obtained expenditure savings may be interpreted as an efficiency gain.

${ }^{23}$ The domicile waste collection is not available for all houses and people are required to take their own waste to specific collection points. 


\section{PLACE TABLE 9 HERE}

\subsection{Local Revenues}

In the analyses conducted so far, we have found that participating to a municipal union reduces local expenditure, while maintaining unchanged (or at least not decreasing) the provision of local services. However, municipalities might have used these savings to lower tax rates.

In order to test this hypothesis, we have collected data on local tax revenues ${ }^{24}$ and used as dependent variable (in per-capita term and transformed in logs) to re-estimate equation 1. The results of this analysis are reported in Table 10. Looking at column 1, for the full sample, participating to a municipal union slightly reduces the local tax revenue by around 2.7 percent, and the effect is statistically significant only at 10 percent. When considering the matched sample, the effect is still negative, and approximately of the same magnitude, however it is not statistically significant. Therefore, we can conclude that taking part in a municipal union might only marginally affect local revenues.

\section{PLACE TABLE 10 HERE}

\footnotetext{
${ }^{24}$ The main local tax revenue is given by the property tax, ICI (Imposta comunale sugli immobili, now renamed IMU, Imposta municipale unica), introduced in 1992 and applied to real estates. This tax is paid every year by property owners directly to the municipality where the property is located. In particular, the ICI tax base is the cadastral income, which does not vary over time (occasionally, cadastral values are increased by the same proportion, so they do not change in relative terms). The tax is levied differently on owner-occupied dwellings (the dwellings where owners have their residence) and on other dwellings (rented properties, secondary properties used for holidays, and so on): tax rates are lower on the former, and tax credits are allowed only for the former. Other important tax revenue sources for municipalities are the tax or tariff on urban waste disposal (Tarsu, now renamed Tari), and a surtax on the personal income levied by the central government (Addizionale comunale Irpef).
} 


\section{CONCLUSION}

Inter-municipal cooperation is a widespread phenomenon among local governments, and it is used by municipalities in order to provide local public services. However, we still know very little about its efficiency. In this study we investigated whether this local form of coordination has an impact on the level of per-capita expenditure of the single municipalities. Each cooperating municipality can exploit economies of scale and internalise externalities, and we test whether there are efficiency gains in terms of local expenditure reduction.

In particular, we analysed the Italian experience of municipal unions, using unique administrative data on the municipalities belonging to the Emilia Romagna region, over the period 2001-2011. We employed a difference-in-differences approach combined with matching models, and we found that participation to a Union reduces the total current per-capita expenditures by around 5 percent, compared to municipalities not in a Union. The effect is persistent and increases up to six years from entrance. Moreover, by using measures of municipality attractiveness and indicator of efficiency, we did not find any decrease in the quality of local public services. Finally, our results are still confirmed when we repeat our main analysis considering municipalities located in Toscana, a neighbouring region very sim-

ilar to Emilia Romagna. We can, therefore, conclude that the municipal union is an effective tool to increase municipalities efficiency. 


\section{Acknowledgements}

We thank seminar audience at the 32nd annual congress of the European Economic Association, at the 70th European meeting of the Econometric society held in Lisbon and at the XXIX Conference of the Italian Society of Public Economics held in Catania. Riccardo Secomandi has provided excellent assistance with the data. The scientific output expressed does not imply a policy position of the European Commission. Neither the European Commission nor any person acting on behalf of the Commission is responsible for the use which might be made of this publication. Leonzio Rizzo thankfully acknowledges the financial support received from the Spanish Ministry of Economy and Competitiveness [grant number ECO2012-37873] and also from Bando FIRB. 


\section{References}

Allers, M. A. and de Greef, J. (2017). Intermunicipal cooperation, public spending and service levels. Local Government Studies, 0(0):1-24.

Allers, M. A. and Geertsema, J. B. (2016). The effects of local government amalgamation on public spending, taxation, and service levels: evidence from 15 years of municipal consolidation. Journal of Regional Science, 56:659-682.

Autor, D. (2003). Outsourcing at will: The contribution of unjust dismissal doctrine to the growth of employment outsourcing. Journal of labor economics, 21(1):1-42.

Bel, G., Fageda, X., and Mur, M. (2012). Does cooperation reduce service delivery costs? evidence from residential solid waste services. Journal of Public Administration Research and Theory, 21(1):1053-1858.

Bel, G. and Warner, M. E. (2015). Factors explaining inter-municipal cooperation in service delivery: a meta-regression analysis. Journal of Economic Policy Reform, pages 1-25.

Blaeschke, F. (2014). What drives small municipalities to cooperate? evidence from hessian municipalities. Joint Discussion Paper Series in Economics 14-2014.

Blesse, S. and Baskaran, T. (2016). Do municipal mergers reduce costs? evidence from a german federal state. Regional Science and Urban Economics, 59:54-74.

Brasington, D. (2003). Size and school district consolidation: Do opposites attract? Economica, 70(280):673-690.

Brasington, D. M. (1999). Joint provision of public goods: the consolidation of school districts. Journal of Public Economics, 73(3):373-393.

Carr, J. B., Gerber, E. R., and Lupher, E. W. (2007). Explaining horizontal and vertical cooperation on public services in Michigan: The role of local fiscal capacity. R. Jelier and G. Sands. East Lansing: Michigan State University Press. 
Case, A. C., Rosen, H. S., and Hines, J. R. (1993). Budget spillovers and fiscal policy interdependence: Evidence from the states. Journal of public economics, 52(3):285-307.

Di Porto, E., Merlin, V. R., and Paty, S. (2013). Cooperation among local governments to deliver public services: A'structural'bivariate response model with fixed effects and endogenous covariate. GATE Groupe d'Analyse et de Théorie Économique Lyon-St Étienne Working Paper No. WP 1304, 1304.

Di Porto, E., Parenti, A., Paty, S., and Abidi, Z. (2016). Local government cooperation at work: a control function approach. Journal of Economic Geography, pages 1-29.

Dollery, B., Crase, L., and Johnson, A. (2006). Australian local government economics. UNSW Press.

Feiock, R. C. (2007). Rational choice and regional governance. Journal of Urban Affairs, $29(1): 47-63$.

Feiock, R. C. and Scholz, J. T. (2009). Self-organizing federalism: Collaborative mechanisms to mitigate institutional collective action dilemmas. Cambridge University Press.

Ferraresi, M., Migali, G., and Rizzo, L. (2018). Spillover effects in local public spending. Regional Studies.

Fritz, B. and Feld, L. P. (2015). The political economy of municipal amalgamation-evidence of common pool effects and local public debt.

Galiani, S., Gertler, P., and Schargrodsky, E. (2005). Water for life: The impact of the privatization of water services on child mortality. Journal of Political Economy, 113(1):83120.

Hanes, N. (2015). Amalgamation impacts on local public expenditures in sweden. Local Government Studies, 4(1):63-77. 
Hansen, S. W. (2014). Common pool size and project size: an empirical test on expenditures using danish municipal mergers. Public Choice, 159(1):3-21.

Hansen, S. W., Houlberg, K., and Pedersen, L. H. (2014). Do municipal mergers improve fiscal outcomes? Scandinavian Political Studies, 37(2):196-214.

Heckman, J. J., Ichimura, H., and Todd, P. E. (1998). Matching as an econometric evaluation estimator. Review of Economic Studies, 65(2):261-294.

Hinnerich, B. T. (2009). Do merging local governments free ride on their counterparts when facing boundary reform? Journal of Public Economics, 93(5):721 - 728.

Hulst, R., van Montfort, A., Haveri, A., Airaksinen, J., and Kelly, J. (2009). Institutional shifs in inter-municpal service delivery. Public Organization Review, 9:263-285.

Jenkins, S. P. (1995). Easy estimation methods for discrete-time duration models. Oxford bulletin of economics and statistics, 57(1):129-136.

Jordahl, H. and Liang, C.-Y. (2010). Merged municipalities, higher debt: on free-riding and the common pool problem in politics. Public Choice, 143(1):157-172.

Kauder, B. (2016). Incorporation of municipalities and population growth: A propensity score matching approach. Papers in Regional Science, 95(3):539-554.

LeRoux, K. and Carr, J. B. (2007). Explaining local government cooperation on public works evidence from michigan. Public Works Management $\mathcal{E}$ Policy, 12(1):344-358.

Lima, R. C. d. A. and Silveira Neto, R. d. M. (2018). Secession of municipalities and economies of scale: Evidence from brazil. Journal of Regional Science, 58:159-180.

Mello, L. and Lago-Penas, S. (2013). The Challange of Local Government Size, chapter Local Government Cooperation for Joint Provision: The Experiences of Brazil and Spain with Inter-Municipal Consortia, pages 221-241. UK: Edward Elgar. 
Moisio, A. and Uusitalo, R. (2013). The impact of municipal mergers on local public expenditures in finland. Public Finance and Management, 13(3):148.

Morgan, D. R. and Hirlinger, M. W. (1991). Intergovernmental service contracts a multivariate explanation. Urban affairs review, 27(1):128-144.

Narendranathan, W. and Stewart, M. B. (1993). How does the benefit effect vary as unemployment spells lengthen? Journal of Applied Econometrics, 8(4):361-381.

Oates, W. E. (1972). Fiscal federalism. Books.

Post, S. (2002). Local government cooperation: The relationship between metropolitan area government geography and service provision.

Reingewertz, Y. (2012). Do municipal amalgamations work? evidence from municipalities in israel. Journal of Urban Economics, 72(2):240-251.

Revelli, F. (2003). Reaction or interaction? spatial process identification in multi-tiered government structures. Journal of Urban Economics, 53(1):29 - 53.

Roesel, F. (2017). Do mergers of large local governments reduce expenditures? evidence from germany using the synthetic control method. European Journal of Political Economy, 50(Supplement C):22-36.

Saarimaa, T. and Tukiainen, J. (2015). Common pool problems in voluntary municipal mergers. European Journal of Political Economy, 38:140-152.

Smith, J. A. and Todd, P. E. (2005). Does matching overcome lalonde's critique of nonexperimental estimators? Journal of econometrics, 125(1):305-353.

Solè-Ollè, A. (2006). Expenditure spillovers and fiscal interactions: Empirical evidence from local governments in spain. Journal of Urban Economics, 59(1):32 - 53. 
van Montfort, A. and Hulst, J. (2011). Institutional features of inter-municipal cooperation: Cooperative arrangements and their national contexts. Public Policy and Administration, 27:121-144.

Veiga, L. G. and Veiga, F. J. (2007). Political business cycles at the municipal level. Public Choice, 131(1):45-64.

Weingast, B. R., Shepsle, K. A., and Johnsen, C. (1981). The political economy of benefits and costs: A neoclassical approach to distributive politics. Journal of Political Economy, $89(4): 642-664$. 
Figure 1: Emilia Romagna municipalities - 2001

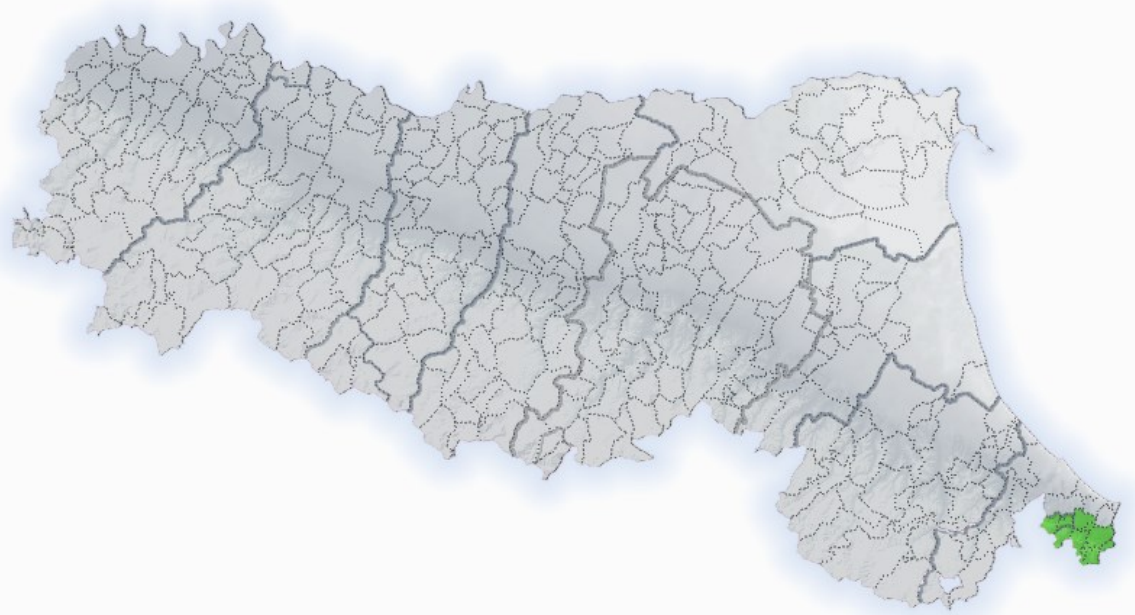

Note: Municipalities and Municipal Unions in year 2001. Municipalities belonging to the same Municipal Union share the same color. 
Figure 2: Emilia Romagna municipalities - 2011

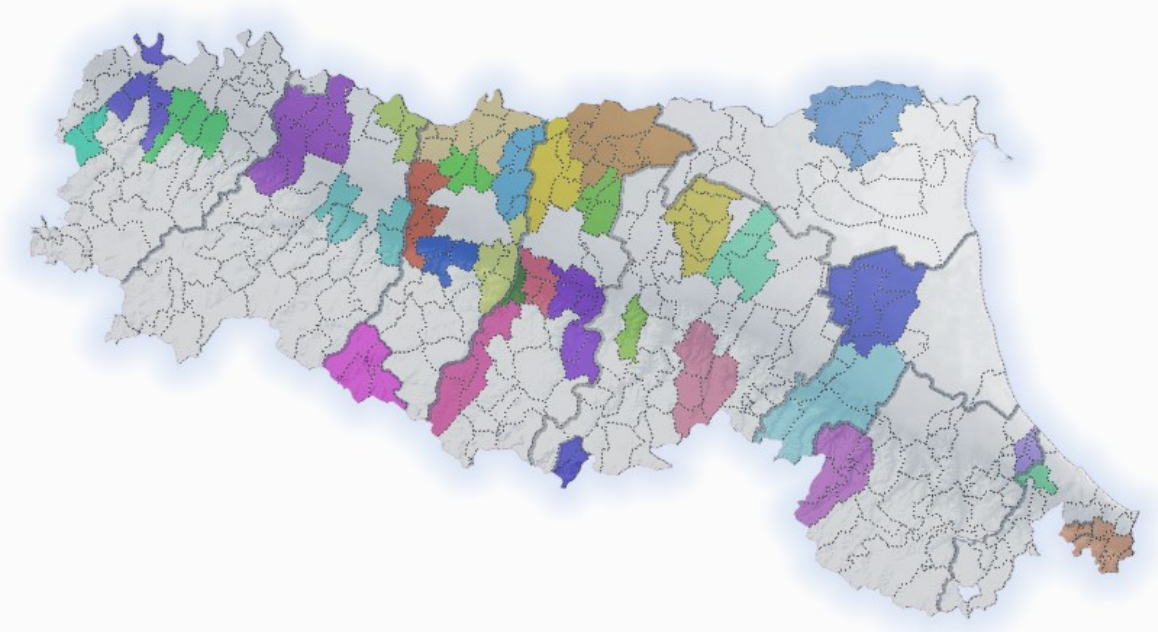

Note: Municipalities and Municipal Unions in year 2001. Municipalities belonging to the same Municipal Union share the same color. 
Figure 3: Evolution of expenditures - 2001-2011

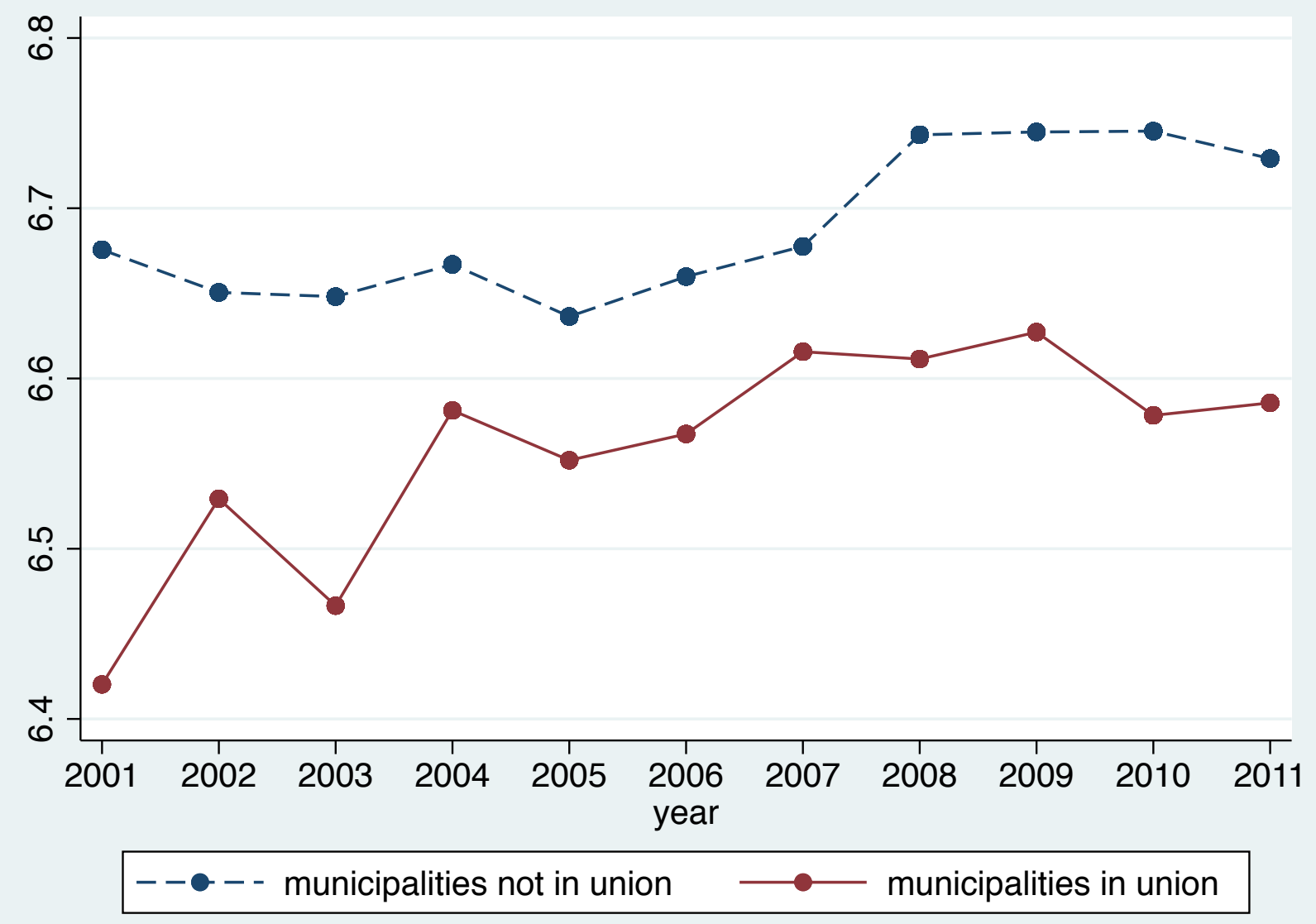


Figure 4: Testing common trend assumption

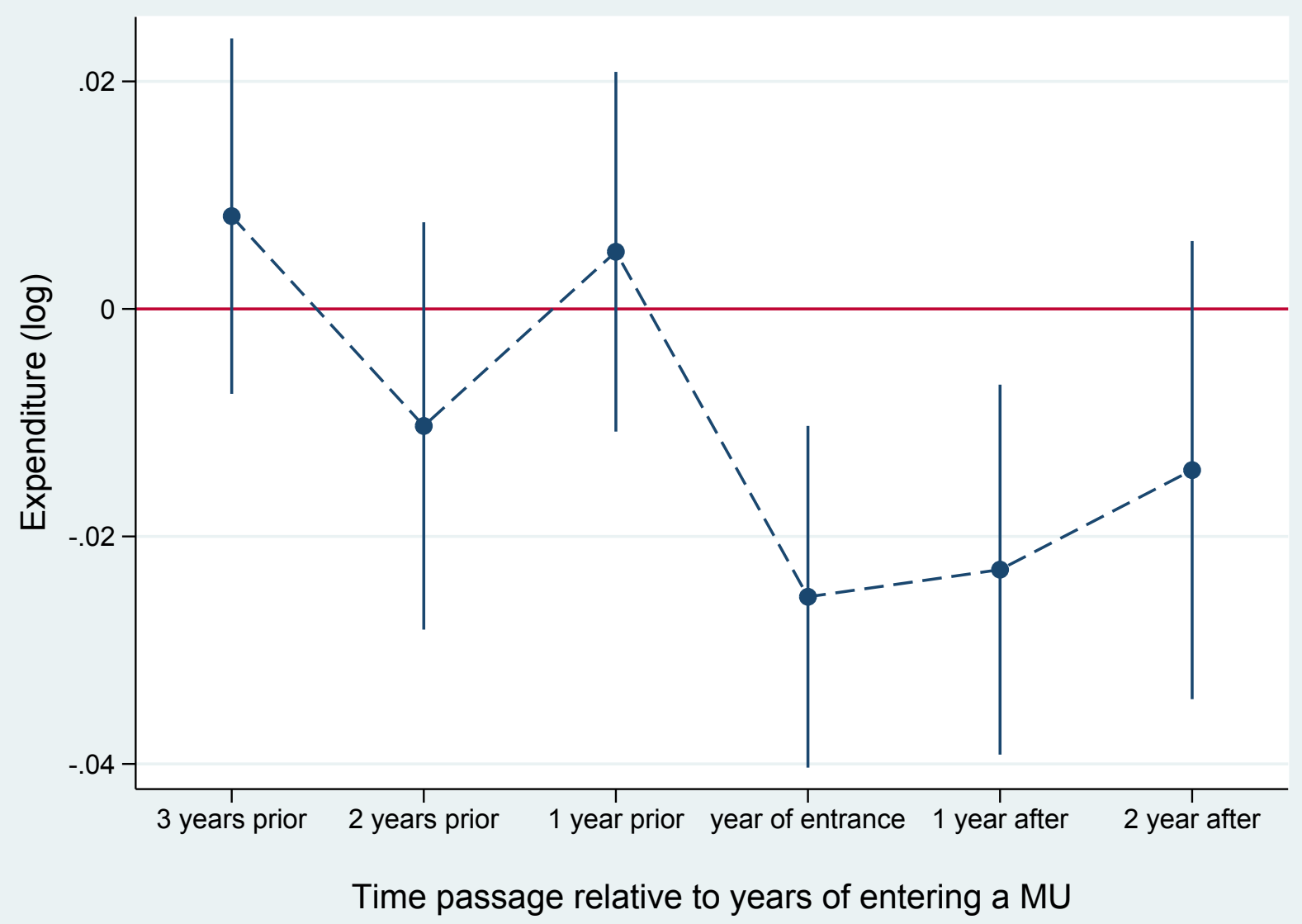




\section{Table 1: Municipalities in Unions in Emilia Romagna 2001-2011}

\begin{tabular}{|c|c|c|c|c|c|}
\hline Year & Municipal Unions & Municipalities not in Unions & Municipalities in Unions & $\%$ of Municipalities in Unions & Total Municipalities \\
\hline 2001 & 1 & 328 & 9 & 2.67 & 337 \\
\hline 2003 & 5 & 303 & 23 & 7.06 & 326 \\
\hline 2005 & 6 & 303 & 32 & 9.55 & 335 \\
\hline 2006 & 10 & 277 & 52 & 15.81 & 329 \\
\hline 2007 & 10 & 281 & 54 & 16.12 & 335 \\
\hline 2010 & 29 & 193 & 150 & 43.73 & 343 \\
\hline 2011 & 31 & 180 & 160 & 47.06 & 340 \\
\hline
\end{tabular}

Table 2: Effect of the Union on Log Expenditures

\begin{tabular}{|c|c|c|c|c|c|c|c|}
\hline Dependent variable: & & & & g Expenditu & Ires & & \\
\hline & & Full sample & & & atched samp & & Matching $^{a}$ \\
\hline & (1) & (2) & (3) & (4) & (5) & (6) & (7) \\
\hline Municipal Union & $-0.065^{* * *}$ & $-0.044^{* * *}$ & $-0.028 * *$ & $-0.060 * * *$ & $-0.041^{* * *}$ & $-0.025^{* *}$ & \\
\hline & $(0.012)$ & $(0.012)$ & $(0.012)$ & $(0.012)$ & $(0.013)$ & $(0.012)$ & \\
\hline Permanence & & & $-0.016^{* * *}$ & & & $-0.016^{* * *}$ & \\
\hline & & & $(0.006)$ & & & $(0.006)$ & \\
\hline Permanence square & & & $0.002^{* * *}$ & & & $0.002^{* * *}$ & \\
\hline & & & $(0.000)$ & & & $(0.000)$ & \\
\hline Union $_{08-10}$ & & & & & & & $\begin{array}{r}-0.055^{* *} \\
(0.023)\end{array}$ \\
\hline $\mathrm{N}$ & 3686 & 3686 & 3686 & 3335 & 3335 & 3335 & 332 \\
\hline Year FE & $\checkmark$ & $\checkmark$ & $\checkmark$ & $\checkmark$ & $\checkmark$ & $\checkmark$ & $\checkmark$ \\
\hline Municipality FE & $\checkmark$ & $\checkmark$ & $\checkmark$ & $\checkmark$ & $\checkmark$ & $\checkmark$ & \\
\hline Municipality controls & & $\checkmark$ & $\checkmark$ & & $\checkmark$ & $\checkmark$ & \\
\hline Standard errors cluste & ed at munic & cipality level & . Significar & ce levels: $* *$ & $* 1 \% * * 5 \%$ & $* 10 \%$ & \\
\hline Municipality controls: & population, & area p.c., & oung $(\leq 5)$ & and old popr & ulation $(\geq 6$ & & \\
\hline $1 /$ population, income, & election, tax & xpayers. & 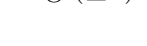 & & & & \\
\hline${ }^{a}$ Kernel difference in & lifferences $\mathrm{m}$ & natching. & nntrol grou & : municipal & & n Union. & \\
\hline Treatment group: mu & icipalities tl & hat joined & Union in 2 & 009. Sample & size restric & ted to 2008 & and 2010, \\
\hline
\end{tabular}


Table 3: Permanence in the municipal union

\begin{tabular}{|c|c|c|c|}
\hline \multirow[t]{2}{*}{ Dependent variable: } & \multicolumn{3}{|c|}{ Log Expenditures - 2001-2011 } \\
\hline & $\begin{array}{r}\text { Full sample } \\
(1)\end{array}$ & $\begin{array}{r}\text { Matched sample } \\
\text { (2) }\end{array}$ & N. Municipalities \\
\hline 1 year & $\begin{array}{r}-0.043^{* * *} \\
(0.012)\end{array}$ & $\begin{array}{r}-0.039^{* * *} \\
(0.013)\end{array}$ & 160 \\
\hline 2 years & $\begin{array}{r}-0.055^{* * *} \\
(0.014)\end{array}$ & $\begin{array}{r}-0.050^{* * *} \\
(0.014)\end{array}$ & 150 \\
\hline 3 years & $\begin{array}{r}-0.064^{* * *} \\
(0.017)\end{array}$ & $\begin{array}{r}-0.058^{* * * *} \\
(0.017)\end{array}$ & 132 \\
\hline 4 years & $\begin{array}{r}-0.069^{* * *} \\
(0.019)\end{array}$ & $\begin{array}{r}-0.062^{* * * *} \\
(0.020)\end{array}$ & 70 \\
\hline 5 years & $\begin{array}{r}-0.072^{* * * *} \\
(0.022)\end{array}$ & $\begin{array}{r}-0.063^{* * *} \\
(0.022)\end{array}$ & 54 \\
\hline 6 years & $\begin{array}{r}-0.072^{* * *} \\
(0.024)\end{array}$ & $\begin{array}{r}-0.060^{* * * *} \\
(0.025)\end{array}$ & 52 \\
\hline 7 years & $\begin{array}{r}-0.068^{* *} \\
(0.027)\end{array}$ & $\begin{array}{r}-0.055^{* *} \\
(0.027)\end{array}$ & 32 \\
\hline 8 years & $\begin{array}{r}-0.062^{* *} \\
(0.029)\end{array}$ & $\begin{array}{r}-0.046 \\
(0.030)\end{array}$ & 32 \\
\hline 9 years & $\begin{array}{l}-0.053^{*} \\
(0.032)\end{array}$ & $\begin{array}{r}-0.033 \\
(0.032)\end{array}$ & 23 \\
\hline 10 years & $\begin{array}{l}-0.040 \\
(0.035)\end{array}$ & $\begin{array}{l}-0.017 \\
(0.035)\end{array}$ & 23 \\
\hline 11 years & $\begin{array}{l}-0.025 \\
(0.038)\end{array}$ & $\begin{array}{r}0.002 \\
(0.038)\end{array}$ & 9 \\
\hline
\end{tabular}


Table 4: Effect of the Union by municipality size

\begin{tabular}{|c|c|c|c|c|}
\hline \multirow[t]{3}{*}{ Dependent variable: } & \multicolumn{3}{|c|}{ Log Expenditures } & \\
\hline & \multicolumn{2}{|c|}{ Full sample } & \multicolumn{2}{|c|}{ Matched sample } \\
\hline & (1) & $(2)$ & $(3)$ & (4) \\
\hline \multirow[t]{2}{*}{ Municipal Union } & $-0.034^{* *}$ & $-0.052^{*}$ & $-0.034^{* *}$ & -0.046 \\
\hline & $(0.017)$ & $(0.030)$ & $(0.017)$ & $(0.031)$ \\
\hline \multirow[t]{2}{*}{ Municipal Union $\times$ Large } & -0.024 & & -0.017 & \\
\hline & $(0.021)$ & & $(0.023)$ & \\
\hline \multirow[t]{2}{*}{ Large } & -0.028 & & -0.023 & \\
\hline & $(0.035)$ & & $(0.035)$ & \\
\hline \multirow[t]{2}{*}{ Municipal Union $\times$ Union size } & & 0.001 & & 0.001 \\
\hline & & $(0.005)$ & & $(0.005)$ \\
\hline $\mathrm{N}$ & 3686 & 3686 & 3335 & 3335 \\
\hline Year FE & $\checkmark$ & $\checkmark$ & $\checkmark$ & $\checkmark$ \\
\hline Municipality FE & $\checkmark$ & $\checkmark$ & $\checkmark$ & $\checkmark$ \\
\hline Municipality controls & $\checkmark$ & $\checkmark$ & $\checkmark$ & $\checkmark$ \\
\hline
\end{tabular}

Standard errors clustered at municipality level.

Significance levels: *** $1 \% * * 5 \% * 10 \%$.

Large: municipality population $\geq 8000$ inhabitants.

Union size: number of municipalities in Union.

Municipality controls: see Table 2.

Table 5: Estimates of the effect of the expenditures on the probability to join the union

\begin{tabular}{|c|c|c|c|c|c|c|c|c|c|}
\hline \multirow{3}{*}{ Dependent variable: } & \multicolumn{8}{|c|}{ Duration Models } & Municipal Union \\
\hline & \multicolumn{5}{|c|}{ Homogenous } & \multicolumn{4}{|c|}{ Heterogenous } \\
\hline & Coeff. & s.e & $\begin{array}{c}\text { Hazard } \\
\text { Ratio }\end{array}$ & $\log L$ & Coeff. & s.e & $\begin{array}{c}\text { Hazard } \\
\text { Ratio }\end{array}$ & $\log L$ & $P-v a l^{*}$ \\
\hline Log expenditures & -0.317 & $(0.330)$ & 0.729 & -473.537 & -0.317 & $(0.330)$ & 0.729 & -473.537 & 0.496 \\
\hline
\end{tabular}


Table 6: Effect of the Union including Transfers

\begin{tabular}{|c|c|c|c|c|c|c|}
\hline \multirow[t]{3}{*}{ Dependent variable: } & \multicolumn{6}{|c|}{ Log Expenditures } \\
\hline & \multicolumn{3}{|c|}{ Full sample } & \multicolumn{3}{|c|}{ Matched sample } \\
\hline & $(1)$ & $(2)$ & $(3)$ & $(4)$ & $(5)$ & (6) \\
\hline Municipal Union & $\begin{array}{r}-0.047^{* * *} \\
(0.013)\end{array}$ & $\begin{array}{r}-0.046^{* * *} \\
(0.015)\end{array}$ & $\begin{array}{r}-0.052^{* * *} \\
(0.015)\end{array}$ & $\begin{array}{r}-0.043^{* * *} \\
(0.013)\end{array}$ & $\begin{array}{r}-0.043^{* * *} \\
(0.015)\end{array}$ & $\begin{array}{r}-0.050^{* * *} * \\
(0.015)\end{array}$ \\
\hline State grants & & $\begin{array}{r}0.001 \\
(0.000)\end{array}$ & & & $\begin{array}{r}0.001 \\
(0.000)\end{array}$ & \\
\hline Regional grants & & $\begin{array}{r}0.000 \\
(0.000)\end{array}$ & & & $\begin{array}{r}0.000 \\
(0.000)\end{array}$ & \\
\hline Other bodies grants & & $\begin{array}{c}0.000^{*} \\
(0.000)\end{array}$ & & & $\begin{array}{c}0.000^{* *} \\
(0.000)\end{array}$ & \\
\hline Other Revenues & & $\begin{array}{r}-0.001^{* *} \\
(0.000)\end{array}$ & & & $\begin{array}{r}-0.001^{* *} \\
(0.000)\end{array}$ & \\
\hline Union revenues by municipalities & & & $\begin{array}{r}0.000 \\
(0.000)\end{array}$ & & & $\begin{array}{r}0.000 \\
(0.000)\end{array}$ \\
\hline $\mathrm{N}$ & 3606 & 3606 & 3606 & 3255 & 3255 & 3255 \\
\hline Year and Municipality FE & $\checkmark$ & $\checkmark$ & $\checkmark$ & $\checkmark$ & $\checkmark$ & $\checkmark$ \\
\hline Municipality controls & $\checkmark$ & $\checkmark$ & $\checkmark$ & $\checkmark$ & $\checkmark$ & $\checkmark$ \\
\hline
\end{tabular}

Table 7: More homogeneous control groups

\begin{tabular}{lcr}
\hline \hline Dependent variable: & \multicolumn{2}{c}{ Log Expenditures - 2001-2008 } \\
& Full sample & Matched sample \\
& $(1)$ & $(2)$ \\
Municipal Union & $-0.069^{* * *}$ & $-0.066^{* * *}$ \\
& $(0.018)$ & $(0.018)$ \\
N & 1217 & 1138 \\
Year FE & $\checkmark$ & $\checkmark$ \\
Municipality FE & $\checkmark$ & $\checkmark$ \\
Municipality controls & $\checkmark$ & $\checkmark$ \\
\hline Standard errors clustered at municipality level. \\
Significance levels: *** $1 \% * * 5 \% * 10 \%$. \\
Control group includes future treated. \\
Municipality controls: see Table 2.
\end{tabular}


Table 8: Effect of Municipal Union in Toscana

\begin{tabular}{lrr}
\hline \hline Dependent variable: & \multicolumn{2}{c}{ Log Expenditures } \\
& Full sample & Matched sample \\
& $(1)$ & $(2)$ \\
Municipal Union & $-0.035^{* *}$ & $-0.026^{*}$ \\
& $(0.015)$ & $(0.016)$ \\
$\mathrm{N}$ & 2893 & 2475 \\
Year FE & $\checkmark$ & $\checkmark$ \\
Municipality FE & $\checkmark$ & $\checkmark$ \\
Municipality controls & $\checkmark$ & $\checkmark$ \\
\hline Standard errors clustered at municipality level. \\
Significance levels: ${ }^{* * *} 1 \%{ }^{* *} 5 \%$ * $10 \%$. \\
Municipality controls: similar as those used \\
for Emilia Romagna see Table 2.
\end{tabular}


Table 9: Effect of the Union on alternative output

\begin{tabular}{|c|c|c|c|c|c|c|}
\hline \multicolumn{7}{|l|}{ Panel A: Attractiveness } \\
\hline & \multicolumn{3}{|c|}{ Full sample } & \multicolumn{3}{|c|}{ Matched sample } \\
\hline & $\begin{array}{c}\text { Birth rate } \\
\text { p.c. } \\
\text { (1) }\end{array}$ & $\begin{array}{l}\text { Number of } \\
\text { children } \\
\text { enrolled } \\
(2)\end{array}$ & $\begin{array}{c}\text { Net } \\
\text { Migration } \\
(3)\end{array}$ & $\begin{array}{l}\text { Birth } \\
\text { rate p.c. } \\
\text { (4) }\end{array}$ & $\begin{array}{c}\text { Number of } \\
\text { children } \\
\text { enrolled } \\
(5)\end{array}$ & $\begin{array}{c}\text { Net } \\
\text { migration } \\
(6)\end{array}$ \\
\hline \multirow[t]{2}{*}{ Municipal Union } & 0.000 & 0.000 & -3.877 & 0.000 & 0.000 & -2.124 \\
\hline & $(0.000)$ & $(0.000)$ & $(7.382)$ & $(0.000)$ & $(0.000)$ & $(6.523)$ \\
\hline $\mathrm{N}$ & 3686 & 2351 & 3686 & 3335 & 2123 & 3335 \\
\hline \multicolumn{7}{|c|}{ Panel B: Efficiency of local services } \\
\hline & \multicolumn{3}{|c|}{ Full sample } & \multicolumn{3}{|c|}{ Matched sample } \\
\hline & $\begin{array}{c}\text { Road } \\
\text { crash p.c. } \\
\text { (1) }\end{array}$ & $\begin{array}{c}\text { Kindergarten } \\
\text { supply } \\
(2)\end{array}$ & $\begin{array}{c}\text { Waste } \\
\text { collection } \\
(3)\end{array}$ & $\begin{array}{c}\text { Road } \\
\text { crash p.c. } \\
\text { (4) }\end{array}$ & $\begin{array}{l}\text { Kindergarten } \\
\text { supply } \\
(5)\end{array}$ & $\begin{array}{c}\text { Waste } \\
\text { collection } \\
(6)\end{array}$ \\
\hline \multirow[t]{2}{*}{ Municipal Union } & -0.000 & $4.303^{* * *}$ & 1.862 & -0.000 & $4.318^{* * *}$ & 1.760 \\
\hline & $(0.000)$ & $(1.563)$ & $(1.441)$ & $(0.000)$ & $(1.584)$ & $(1.441)$ \\
\hline $\mathrm{N}$ & 3592 & 2120 & 2326 & 3265 & 1972 & 2113 \\
\hline Year and Municipality FE & $\checkmark$ & $\checkmark$ & $\checkmark$ & $\checkmark$ & $\checkmark$ & $\checkmark$ \\
\hline Municipality controls & $\checkmark$ & $\checkmark$ & $\checkmark$ & $\checkmark$ & $\checkmark$ & $\checkmark$ \\
\hline
\end{tabular}

Standard errors clustered at municipality level. Significance levels: *** $1 \% * * 5 \% * 10 \%$.

Municipality controls: see Table 2. 
Table 10: Effect of Municipal Union on Local Tax Revenue

\begin{tabular}{lcr}
\hline \hline Dependent variable: & Local Tax Revenue \\
& Full sample & Matched sample \\
& $(1)$ & $(2)$ \\
Municipal Union & $-0.027^{*}$ & -0.021 \\
& $(0.014)$ & $(0.014)$ \\
N & 3686 & 3335 \\
Year FE & $\checkmark$ & $\checkmark$ \\
Municipality FE & $\checkmark$ & $\checkmark$ \\
Municipality controls & $\checkmark$ & \\
\hline Standard errors clustered at municipality level. & \\
Significance levels: $* * *$ & $1 \% * * 5 \% * 10 \%$. & \\
Municipality controls: see Table 2. &
\end{tabular}


A Appendix 
Table A.1: Data sources

\begin{tabular}{|c|c|c|c|}
\hline Variable & Definition and measure & Available from-to & Source \\
\hline Log expenditure & Log of current expenditure per resident; 2011 Euros & 2001-2011 & Italian Ministry of Interior \\
\hline Municipal Union & $\begin{array}{l}\text { Dummy variable that takes on the value one if municipality i } \\
\text { at time } t \text { belongs to a Municipal Union and zero otherwise. }\end{array}$ & 2001-2011 & Italian Ministry of Interior \\
\hline Birth rate per capita & Birth rate per capita & 2001-2011 & ISTAT \\
\hline Number of children enrolled & Number of children enrolled in infant school (per-capita) & 2004-2011 & ISTAT \\
\hline Net migration & Difference between new registered members and unregistered members & 2001-2011 & ISTAT \\
\hline Per capita road crash & Number of accidents within the municipal roads & 2001-2011 & ISTAT \\
\hline Taxpayers & Share of the taxpayers of the municipality & 2001-2011 & Italian Ministry of Economy, Department of Finance \\
\hline Population & Population of the municipality & 2001-2011 & ISTAT \\
\hline Population 5 & Share of the population aged between $0-5$ & 2001-2011 & ISTAT \\
\hline Population 65 & Share of the population over the age of 65 & 2001-2011 & ISTAT \\
\hline Area per capita & Area (square kilometers) divided by numbers of citizens per area & 2001-2011 & Our computation \\
\hline Income & Real personal income tax base per resident; 2011 Euros & 2001-2011 & Italian Ministry of Economy, Department of Finance \\
\hline 1/population & Inverse of the population & 2001-2011 & Our computation \\
\hline Permanence & Number of years joining the Municipal Union & 2001-2011 & Our computation \\
\hline \multirow[t]{2}{*}{ Election } & Dummy variable that takes the value of one & & \\
\hline & if municipality $\mathrm{i}$ at time $\mathrm{t}$ has an election and zero otherwise & 2001-2011 & Italian Ministry of Interior \\
\hline Kindergarden supply & Number of applications submitted to the kindergarten / number of satisfied applications & 2001-2011 & Italian Ministry of Interior \\
\hline Waste collection & Number of houses served by the domicile municipal service of waste collection/ total number of houses & 2001-2011 & Italian Ministry of Interior \\
\hline Log Local Tax revenues & Log of revenues of local taxes per resident; 2011 Euros & 2001-2011 & Italian Ministry of Interior \\
\hline State grants & Grants from the State to the Municipal Union & 2001-2011 & Italian Ministry of Interior \\
\hline Regional grants & Grants from the Region Emilia Romagna to the Municipal Union & 2001-2011 & Italian Ministry of Interior \\
\hline Other bodies grants & Grants from other body (municipalities and provinces) to the Municipal Union & 2001-2011 & Italian Ministry of Interior \\
\hline Other Revenues & Other revenues of the Municipal Union & 2001-2011 & Italian Ministry of Interior \\
\hline Union revenues by municipalities & Total revenues of the municipal Union divided by municipalities & 2001-2011 & Italian Ministry of Interior \\
\hline \multirow[t]{2}{*}{ Large } & Dummy variable that takes the value of one & & \\
\hline & if a municipality $\mathrm{i}$ at time $\mathrm{t}$ has more than 8000 inhabitants and zero otherwise & 2001-2011 & ISTAT \\
\hline Union size & number of municipalities forming a given Municipal Union & 2001-2011 & Our computation \\
\hline Permanence square & Square of number of years joining the Municipal Union & 2001-2011 & Our computation \\
\hline Seismic area & Dummy variable equals to 1 if the municipality is located in a seismic zone & 2001 & ISTAT \\
\hline Rural area & $\begin{array}{l}\text { Dummy variable equals to } 1 \text { if the municipality is a rural municipality and zero otherwise. } \\
\text { Rural communities are defined as municipalities that meet the definition of Eurostat: } \\
\text { population density (population per kmq) less than } 100 \text { inhabitants per square kilometer }\end{array}$ & & \\
\hline \multirow{3}{*}{ Altitude profile } & or $\%$ of employed in agriculture above the Community average. & 2001 & ISTAT \\
\hline & $\begin{array}{l}\text { Categorical variable equal to } 1 \text { if the municipality is located in plain, } \\
\text { equal to } 2 \text { if the municipality is located on hills. }\end{array}$ & & \\
\hline & and equal to 3 if the municipality is located in mountains; municipal unemployment rate & 2001 & ISTAT \\
\hline Unemployment & Municipal unemployment rate & 2001 & ISTAT \\
\hline Dwellings & Number of houses & 2001 & ISTAT \\
\hline Firms & Number of firms & 2001 & ISTAT \\
\hline Debts & Municipal debts in per capita term & 2001 & Italian Ministry of Interior \\
\hline
\end{tabular}


Table A.2: Municipalities in Unions in Emilia Romagna 2001-2011

\begin{tabular}{lccccc} 
Variables & Obs & Mean & Std. Dev. & Min & Max \\
\hline Log expenditure & 3,686 & 6.66 & 0.29 & 5.73 & 8.33 \\
Municipal Union & 3,686 & 0.20 & 0.40 & 0.00 & 1.00 \\
Population & 3,686 & $11,419.58$ & $23,150.21$ & 91.00 & $186,690.00$ \\
Population $\leq 5$ & 3,686 & 0.05 & 0.01 & 0.00 & 0.08 \\
Population $\geq 65$ & 3,686 & 0.24 & 0.07 & 0.12 & 0.64 \\
Income & 3,686 & $13,223.43$ & $2,086.34$ & $5,425.24$ & $20,525.25$ \\
Area (per capita) & 3,686 & 0.02 & 0.02 & 0.00 & 0.27 \\
Taxpayers & 3,686 & 0.71 & 0.10 & 0.32 & 1.08 \\
1/population & 3,686 & 0.00 & 0.00 & 0.00 & 0.01 \\
Election & 3,686 & 0.19 & 0.39 & 0.00 & 1.00 \\
Permanence & 3,686 & 0.60 & 1.82 & 0.00 & 15.00 \\
Permanence square & 3,686 & 3.67 & 16.80 & 0.00 & 225.00 \\
Birth rate per capita & 3,686 & 0.01 & 0.00 & 0.00 & 0.03 \\
N. children in infant school pc & 2,351 & 0.02 & 0.01 & 0.00 & 0.06 \\
Net migration & 3,686 & 42.33 & 122.74 & $-1,773.00$ & $1,366.00$ \\
Per capita road car crash & 3,592 & 0.00 & 0.00 & 0.00 & 0.02 \\
Kindergarten supply & 2,120 & 80.84 & 18.11 & 0.00 & 100.00 \\
Waste collection & 2,326 & 84.15 & 22.40 & 0.00 & 100.00 \\
Log local tax revenue & 3,686 & 6.13 & 0.33 & 4.50 & 7.18 \\
State grants & 3,606 & 0.84 & 5.39 & 0.00 & 120.77 \\
Regional grants & 3,606 & 3.81 & 16.80 & 0.00 & 259.33 \\
Other bodies grants & 3,606 & 12.58 & 46.82 & 0.00 & 378.10 \\
Other Revenues & 3,606 & 7.37 & 27.10 & 0.00 & 292.26 \\
Union revenues by municipalities & 3,606 & 24.61 & 83.61 & 0.00 & 676.55 \\
Large & 3,686 & 0.35 & 0.48 & 0.00 & 1.00 \\
Union size & 3,686 & 1.28 & 2.80 & 0.00 & 10.00 \\
\hline
\end{tabular}


Table A.3: Propensity score model of participation to a Municipal Union

\begin{tabular}{|c|c|}
\hline $\begin{array}{c}\text { Probit Model } \\
\text { Dependent variable: }\end{array}$ & Municipal Union \\
\hline Seismic area & $\begin{array}{r}-0.226 \\
(0.161)\end{array}$ \\
\hline Rural area & $\begin{array}{r}-0.004 \\
(0.195)\end{array}$ \\
\hline Area p.c. & $\begin{array}{r}-13.770 \\
(8.596)\end{array}$ \\
\hline Altitude profile & $\begin{array}{r}0.133^{*} \\
(0.077)\end{array}$ \\
\hline Unemployment & $\begin{array}{r}0.957 \\
(7.313)\end{array}$ \\
\hline Dwellings & $\begin{array}{r}-0.001^{* * * *} \\
(0.000)\end{array}$ \\
\hline Firms & $\begin{array}{r}0.001 \\
(0.001)\end{array}$ \\
\hline Population & $\begin{array}{r}0.000^{* *} \\
(0.000)\end{array}$ \\
\hline Population $\leq 5$ & $\begin{array}{r}50.798 * * * \\
(15.234)\end{array}$ \\
\hline Population $\geq 65$ & $\begin{array}{r}15.033^{* * *} \\
(3.811)\end{array}$ \\
\hline 1/population & $\begin{array}{r}-310.986 \\
(307.871)\end{array}$ \\
\hline Income & $\begin{array}{r}0.000^{* *} \\
(0.000)\end{array}$ \\
\hline Taxpayers & $\begin{array}{r}-7.559^{* *} \\
(3.604)\end{array}$ \\
\hline Debts & $\begin{array}{r}0.000 \\
(0.000)\end{array}$ \\
\hline Constant & $\begin{array}{r}-1.143 \\
(2.974)\end{array}$ \\
\hline $\mathrm{N}$ & 337 \\
\hline
\end{tabular}


Table A.4: Estimates of the effect of the expenditures on the probability to join the union Full model

\begin{tabular}{|c|c|c|}
\hline \multicolumn{3}{|c|}{ Duration Models } \\
\hline \multirow[t]{3}{*}{ Dependent variable: } & \multicolumn{2}{|c|}{ Municipal Union } \\
\hline & Homogenous & Heterogenous \\
\hline & $(1)$ & $(2)$ \\
\hline \multirow[t]{2}{*}{ Log expenditure } & -0.317 & -0.317 \\
\hline & $(0.330)$ & $(0.330)$ \\
\hline \multirow[t]{2}{*}{ Population } & $-0.000 * *$ & $-0.000 * *$ \\
\hline & $(0.000)$ & $(0.000)$ \\
\hline \multirow{2}{*}{ Population $\leq 5$} & $47.285^{* * *}$ & $47.278 * * *$ \\
\hline & $(14.715)$ & $(14.715)$ \\
\hline \multirow[t]{2}{*}{ Population $\geq 65$} & 4.885 & 4.885 \\
\hline & $(4.060)$ & $(4.060)$ \\
\hline \multirow[t]{2}{*}{ Income } & 0.000 & 0.000 \\
\hline & $(0.000)$ & $(0.000)$ \\
\hline \multirow[t]{2}{*}{ Area (p.c.) } & $-28.840 * * *$ & $-28.839 * * *$ \\
\hline & (11.043) & (11.043) \\
\hline \multirow[t]{2}{*}{ Taxpayers } & -0.603 & -0.604 \\
\hline & $(3.235)$ & $(3.235)$ \\
\hline \multirow[t]{2}{*}{ 1/population } & 118.168 & 118.118 \\
\hline & $(329.405)$ & $(329.408)$ \\
\hline \multirow[t]{2}{*}{ Election } & -0.043 & -0.043 \\
\hline & $(0.244)$ & $(0.244)$ \\
\hline \multirow[t]{2}{*}{ Constant } & & -11.467 \\
\hline & & $(17.877)$ \\
\hline $\mathrm{N}$ & 2499 & 2499 \\
\hline 11 & -473.5216 & -473.5216 \\
\hline
\end{tabular}

All models include dummy variables for each period. Significance levels: $* * * 1 \% * * 5 \% * 10 \%$. 
Table A.5: Evaluation of the common trend

\begin{tabular}{lrrrr}
\hline \hline Dependent variable: & \multicolumn{4}{c}{ Log Expenditures } \\
& \multicolumn{1}{c}{ Full sample } & \multicolumn{1}{c}{ Matched sample } \\
& $(1)$ & \multicolumn{1}{c}{$(2)$} & \multicolumn{1}{c}{$(3)$} & \multicolumn{1}{c}{$(4)$} \\
& $-0.046^{* * *}$ & $-0.025^{* * *}$ & $-0.044^{* * *}$ & $-0.025^{* * *}$ \\
Municipal Union & $(0.011)$ & $(0.009)$ & $(0.011)$ & $(0.009)$ \\
& 0.006 & 0.005 & 0.007 & 0.006 \\
lead $_{t+1}$ & $(0.010)$ & $(0.010)$ & $(0.010)$ & $(0.010)$ \\
& -0.011 & -0.010 & -0.010 & -0.010 \\
$\operatorname{lead}_{t+2}$ & $(0.011)$ & $(0.011)$ & $(0.011)$ & $(0.011)$ \\
& 0.013 & 0.008 & 0.012 & 0.008 \\
$\operatorname{lead}_{t+3}$ & $(0.009)$ & $(0.009)$ & $(0.010)$ & $(0.010)$ \\
& & $-0.023^{* *}$ & & $-0.022^{* *}$ \\
$\operatorname{lag}_{t-1}$ & & $(0.010)$ & & $(0.010)$ \\
& & -0.014 & & -0.011 \\
$\operatorname{lag}_{t-2}$ & & $(0.012)$ & & $(0.012)$ \\
& 3686 & 3686 & 3335 & 3335 \\
$\mathrm{~N}$ & $\checkmark$ & $\checkmark$ & $\checkmark$ & $\checkmark$ \\
Year FE & $\checkmark$ & $\checkmark$ & $\checkmark$ & $\checkmark$ \\
Municipality FE & $\checkmark$ & $\checkmark$ & $\checkmark$ & $\checkmark$ \\
Municipality controls & & $\checkmark$ &
\end{tabular}

Standard errors clustered at municipality level.

Significance levels: *** 1\%** 5\%*10\%.

Municipality controls: see Table 2. 